\title{
PRODUÇÃO E CARACTERIZAÇÃO DE MUTANTES DO OPERON GUM DE XYLELLA FASTIDIOSA
}

\section{Leonardo Cesar de Almeida Souza}

Dissertação apresentada à Escola Superior de Agricultura "Luiz de Queiroz", Universidade de São Paulo, para obtenção do título de Mestre em Agronomia, Área de Concentração: Genética e Melhoramento de Plantas.

\author{
PIRACICABA \\ Estado de São Paulo - Brasil \\ Dezembro - 2002
}




\title{
PRODUÇÃO E CARACTERIZAÇÃO DE MUTANTES DO OPERON GUM DE XYLELLA FASTIDIOSA
}

\author{
Leonardo Cesar de Almeida Souza \\ Bacharel em Ciências Biológicas
}

Orientador: Prof. Dr. JoÃo LúcIO dE AZEVEDO

Dissertação apresentada à Escola Superior de Agricultura "Luiz de Queiroz", Universidade de São Paulo, para obtenção do título de Mestre em Agronomia, Área de Concentração: Genética e Melhoramento de Plantas.

\author{
PIRACICABA \\ Estado de São Paulo - Brasil \\ Dezembro - 2002
}


Dados Internacionais de Catalogação na Publicação (CIP) DIVISÃO DE BIBLIOTECA E DOCUMENTAÇÃO - ESALQ/USP

\author{
Souza, Leonardo Cesarde Almeida \\ Produção e caracteriza ção de mutantes do operon gum de Xylella \\ fa stidiosa / Leonardo Cesar de Almeida Souza. - - Piracicaba, 2002. \\ 79 p. : il. \\ Dissertação (mestrado) - - Escola Superior de Agricultura Luiz de \\ Queiroz, 2002. \\ Bibliografia. \\ 1. Bactéria fitopatogênica 2. Clorose variegada doscitros 3. Genética \\ mic robiana 4. Genoma-sequência 5. Mutação 6. Operon gum I. Título \\ CDD 589.9015
}

"Permitida a cópia total ou parcial deste documento, desde que citada a fonte - $\mathrm{O}$ autor" 
“(...) Depois, mal o sol acabou de nascer, o homem e a mulher foram pintar na proa do barco, de um lado e do outro, em letras brancas, o nome que ainda faltava dar a caravela. Pela hora do meio-dia, com a maré, A Ilha Desconhecida fez-se ao mar, à procura de si mesma."

José Saramago 
Dedico este trabalho a meu pai José Almeida

Souza, que me ensinou a viver a vida de forma

intensa e prazerosa. 


\section{AGRADECIMENTOS}

Ao professor João Lúcio de Azevedo, pela orientação e pelo exemplo de conhecimento, competência, caráter e simplicidade;

À amiga e co-orientadora Patrícia Brant Monteiro, pela ajuda essencial e imprescindível durante todo esse trabalho;

A Juliano Ayres, diretor do departamento científico do FUNDECITRUS pelo espaço e material cedido;

Um agradecimento todo especial a minha mãezinha Rita, pelo apoio, amor, compreensão, amizade, suporte, carinho, preocupação, zelo e existência;

A meu falecido pai, José Almeida Souza, que apesar de não presente sempre serviu como estímulo;

A meu querido irmão Hevandro, pelo apoio irrestrito e pela preocupação comigo e com minha saúde;

Ao grande amigo Patrice Gaurivaud, por todos os conhecimentos passados e pela ajuda, sem a qual esse trabalho não seria possível;

A Dr. Dulce e Claudia, do laboratório de cristalografia de proteínas da USP São Carlos, pela ajuda no trabalho com proteínas;

Ao amigo Osmar pelo grande apoio em Araraquara no início desse trabalho;

A Paulo Teixeira Lacava e Walter Maccheroni, pela grande amizade e convívio divertido e agradável;

Aos companheiros e amigos do laboratório de Piracicaba: Profa Aline, Wellington, André, Fernando (mosk), Cláudia, Priscila, Marcelo (D-vagar), 
Fernando (GB), Carol (mucuim), Sérgio, Joelma, Andréia, Juci, Ricardo (pipa), Adalgisa, Luciana, Taís, Júlia, Maira, Cristina, Bia, Zezo, Carlos (Cadu), Chico, Uira e do Fundecitrus em Araraquara: Anelise, Nelson, Caroline, Renata, Andréia, Elaine, Sanvai, Fabrício, Mateus, Renê, Eridan, Diva, Renato, Marcel Pedro, Célia, Belasque e Luciana;

Aos amigos do peito: Anselmo, Ive, Alexandre (Jaca), Alexandre (Tio) Buda, Nakama, Fernanda, Magda, Cris, Fúlvio, Thaís, Érica, DW, Zé, lara, Larissa, Gi, Monique, Marcos (miguelito), Roger, Dani, Limão, Káthia, Dennis, Maristela, Manuela, Liliput, Denise (véia), Victor (Cabrón), Fabio Ortega, Vagnão, Rafael, Bruno, Guimba, Sigoga, Guigão, Lucas e Fabiano.

Ao CNPq pelo apoio financeiro;

A Gregor Mendel e suas ervilhas pela genética... 


\section{SUMÁRIO}

Página

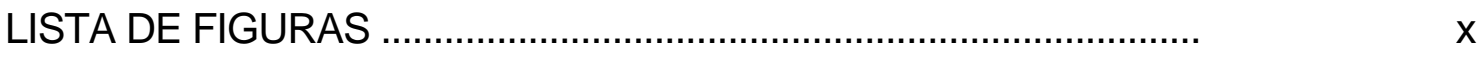

LISTA DE TABELAS ...........................................................

RESUMO ..........................................................................

SUMMARY ........................................................................ XV

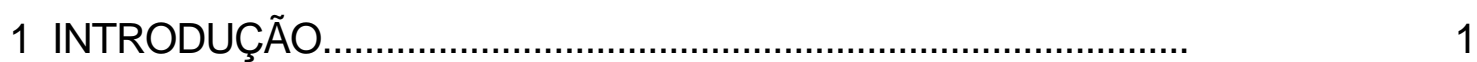

2 REVISÃO DE LITERATURA.................................................

2.1 A Xylella fastidiosa ..................................................................

2.1.1 Generalidades e histórico ..................................................... 3

2.1.2 A Xylella fastidiosa e a Clorose Variegada dos Citros (CVC) ..... 5

2.1.3 O genoma da Xylella fastidiosa ..............................................

2.2 Exopolissacarídos, Biofilmes e seu papel na patogenicidade de bactérias

2.3 A goma fastidiana e a patogênese de Xylella fastidiosa.................

2.3.1 A goma xantana ................................................................... 14

2.3.2 A goma fastidiana ........................................................ 17

2.4 O uso de mutantes para o estudo de um gene............................. 19

2.5 Ferramentas para o estudo de Xylella fastidiosa ........................... 23

2.5.1 Vetores para transformação e disrupção gênica ........................ 23

2.5.2 O uso de hospedeiros alternativos para o estudo da patogênese de Xylella fastidiosa ............................................. 26

3 MATERIAL E MÉTODOS .............................................................. 28 


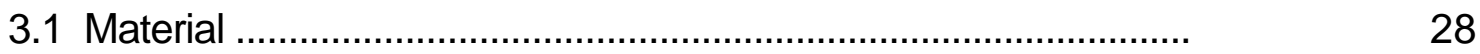

3.1.1 Linhagens bacteriana e condições de cultivo .............................. 28

3.1.2 Enzimas de restrição, enzimas de modificação e kits para biologia molecular ..............................................................

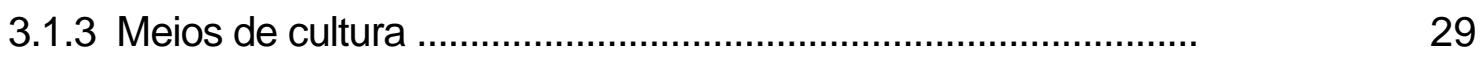

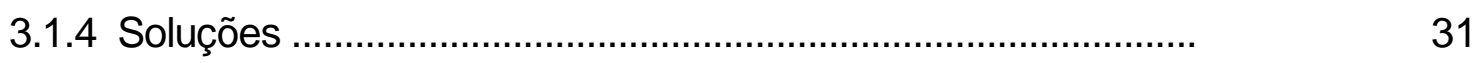

3.1.5 Oligonucleotídeos .............................................................

3.1.6 Plasmídeos ........................................................................

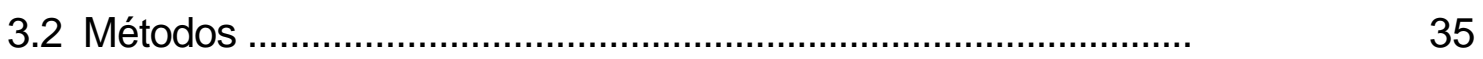

3.2.1 Enzimas de restrição e modificação, PCRs e manipulação de vetores em E. coli ......................................................................

3.2.2 Dimerização dos oligonucleotídeos Tm1 e Tm2 .......................... 36

3.2.3 Preparação de células competentes e transformação de Xylella

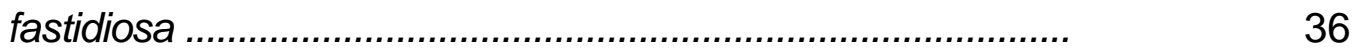

3.2.4 Repiques dos transformantes .............................................. 37

3.2.5 Avaliação da integração por Southern blot e obtenção das culturas puras ..................................................................

3.2.5.1 Extração de DNA ............................................................

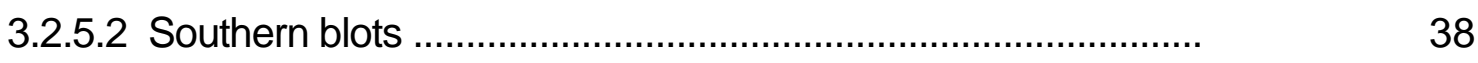

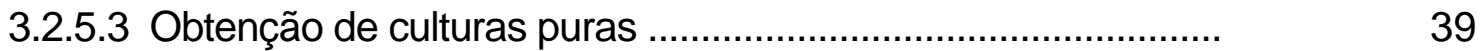

3.2.6 Análise da expressão do gene repórter CAT ............................... 39

3.2.7 Análise morfológica dos mutantes ............................................ 39

3.2.8 Ensaio de adesão em vidro ......................................................

3.2.9 Avaliação do perfil protéico ....................................................... 40

3.2.10 Inoculação dos mutantes gum em plantas de citros e tabaco .. $\quad 41$

3.2.10.1 Inoculação em citros ...........................................................

3.2.10.2 Inoculação em tabaco .........................................................

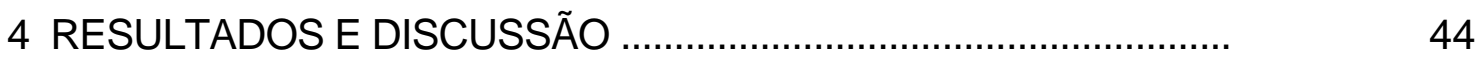

4.1 Construção do plasmídeo pDT8 ..................................................... 
4.1.1 Clonagem do gene Clorafenicol Acetil Transferase (CAT)

4.1.2 Clonagem da origem de origem de replicação (OriC) de Xylella fastidiosa

4.1.3 Clonagem do gene $a a c A . a p h D\left(K^{\prime}{ }^{\prime}\right)$...................................

4.1.4 Clonagem da cauda de tmRNA de Xylella fastidiosa...................

4.2 Construção dos vetores para mutagênese por inserção.deleção (IDM) dos genes gumB, gumD e gumF

4.3 Construção dos vetores para disrupção por troca alélica ( $A E)$ dos genes gum $D$ e gum $F$

4.4 Obtenção dos mutantes por troca alélica (AE)

4.5 Obtenção dos mutantes por inserção.deleção (IDM)

4.6 Obtenção de culturas puras dos mutantes gumB e gumF e determinação da configuração genômica das integrações

4.7 Análise da expressão do gene repórter CAT nos mutantes

4.8 Análise morfológica dos mutantes gumB e gumF

4.9 Avaliação do efeito da mutação nos genes gumB e gumF na adesão de Xylella fastidiosa

4.10 Avaliação do perfil protéico dos mutantes gum

4.11 Inoculações dos mutantes gum em citros e tabaco .

5 CONCLUSÕES 


\section{LISTA DE FIGURAS}

Página

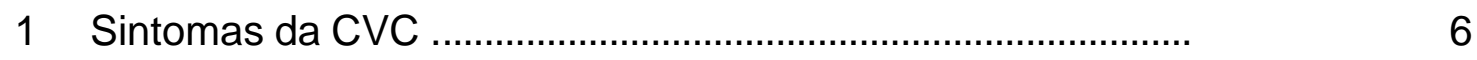

2 Representação esquemática da síntese de goma xantana em Xanthomonas campestris

3 Comparação dos operons gum de $X$. fastidiosa e Xanthomonas campestris

4 Comparação das subunidades da goma xantana e da goma fastidiana

5 Esquema mostrando a IDM ..................................................... 21

6 Esquema mostrando a AE ..................................................... 22

7 Inoculação de Xylella fastidiosa em mudas de laranja .................. 42

8 Amplificação dos genes gumB, gumD e gumF ............................

9 Esquema dos plasmídeos usados para disrupção dos genes

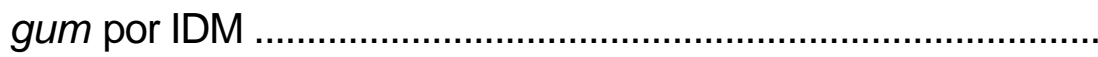

10 Amplificação dos genes AMP e CAT ..........................................

11 Esquema dos plasmídeos usados para disrupção dos genes gum por $\mathrm{AE}$

12 Análise comparativa por Southern blot dos mutantes gumF e gumB

13 Mapa mostrando a organização genômica da região que compreende os genes gumB e gumF 
14 Avaliação da resistência do mutante gumB a clorafenicol em meio PW normal e suplementado com $1 \%$ de glicose .................

15 Avaliação da resistência do mutante gumF a clorafenicol em meio PW normal e suplementado com $1 \%$ de glicose .................

16 Determinação por PCR da orientação do gene CAT em relação aos gene gumF

17 Gráfico da relação entre a densidade óptica das células aderidas e a densidade óptica das células em suspensão no experimento de adesão em vidro

18 Cromatograma mostrando o perfil de proteínas solúveis dos mutantes gumB e gumF e da linhagem selvagem J1a12 ............. 


\section{LISTA DE TABELAS}

Página

1 Oligonucleotídeos utilizados .................................................... 34

2 Concentração de células utilizadas no experimento de

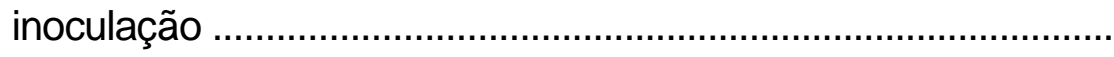




\title{
PRODUÇÃO E CARACTERIZAÇÃO DE MUTANTES DO OPERON GUM DE XYLELLA FASTIDIOSA
}

\author{
Autor: LEONARDO CESAR DE ALMEIDA SOUZA \\ Orientador: Prof. Dr. JOÃO LÚCIO DE AZEVEDO
}

\section{RESUMO}

A Xylella fastidiosa é uma bactéria gram.negativa, fastidiosa, que vive limitada ao xilema de plantas causando várias doenças de importância econômica como a doença de Pierce em videiras nos Estados Unidos e a Clorose Variegada dos Citros (CVC) no Brasil. A CVC tem afetado severamente a citricultura do estado de São Paulo pondo em risco milhares de empregos e milhões de dólares em geração de divisas. O sequenciamento do genoma de $X$. fastidiosa revelou genes envolvidos em possíveis mecanismos de patogenicidade dessa bactéria, entre eles um operon possivelmente envolvido na produção de um exopolissacarídeo extracelular denominado goma fastidiana. Supõe.se que esse exopolissacarídeo seja o responsável pela manutenção dos biofilmes bacterianos que causam a oclusão dos vasos xilemáticos levando ao surgimento dos sintomas da CVC. Para estudar esse operon, denominado operon gum, foram construídos vetores para a inativação dos genes gumB, gumD e gumF por duas estratégias: mutagênese por 
inserção.deleção e mutagênese por troca alélica. A mutagênese por inserção.deleção envolve a integração via recombinação homóloga com uma permuta.de um plasmídeo contendo uma cópia truncada do gene alvo. A mutagênese por troca alélica, por sua vez, envolve duas permutas e se caracteriza pela troca do gene alvo selvagem por uma cópia interrompida por um marcador de seleção. Nenhum mutante gum foi obtido usando.se a estratégia de troca alélica, todavia, mutantes para os genes gumB e gumF foram obtidos com sucesso pela estratégia de mutagênese por inserção.deleção. Nenhum mutante para o gene gumD foi obtido, sugerindo que essa mutação possa ser letal para a célula. A análise de células e colônias desses mutantes crescidos em meio sólido ou em suspensão não mostrou diferenças morfológicas em relação a linhagem selvagem. A inativação dos genes gumB e gumF não influenciou a capacidade de $X$. fastidiosa se aderir a vidro. Com o uso do gene repórter CAT, que codifica para a enzima clorafenicol acetil transferase a qual confere à bactéria resistência ao antibiótico clorafenicol foi possível verificar que a glicose não influencia na expressão desse operon ao nível de transcrição. Com o uso desse gene reporter, também foi possível identificar uma região transcrita a partir de um promotor não caracterizado, localizada na fita antisenso do operon gum. A comparação do perfil cromatográfico de proteínas solúveis totais dos mutantes e da linhagem selvagem mostrou diferenças significativas nesses pefis, indicando um efeito pleiotrópico dessas mutações. O estudo da função dos genes gumB e gumF na patogenicidade de $X$. fastidiosa foi impossibilitado por se ter verificado recentemente que a linhagem usada na construção dos mutantes não coloniza a planta eficientemente para a indução de sintomas em citros e tabaco em condições experimentais após inoculação mecânica 


\title{
PRODUCTION AND CHARACTERIZATION OF GUM OPERON MUTANTS OF XYLELLA FASTIDIOSA CVC STRAIN
}

\author{
Author: LEONARDO CESAR DE ALMEIDA SOUZA \\ Adviser: Prof. Dr. JOÃO LÚCIO DE AZEVEDO
}

\section{SUMMARY}

Xylella fastidiosa is a fastidious, xylem restricted, gram.negative bacteria, that causes several economically important diseases as Pierce's disease of grapevine in USA and the Citrus Variegated Chlorosis (CVC) in Brasil. CVC affects severely the São Paulo State citriculture jeopardizing thousands of jobs and millions of dollars of incomes. The genome sequence of $X$. fastidiosa has revealed several genes possibly involved in the pathogenicity mechanisms of this bacterium, among them, an operon containing nine genes possibly involved in the synthesis of an exopolisaccharide named fastidian gum. This gum is possibly involved in the bacterial biofilm maintenance that causes the xylem occlusion leading to CVC symptoms development. To study this operon, named gum operon, vectors were constructed to inactivate the gumB, gumD and gumF genes by two strategies, insertion.duplication mutagenesis and allelic exchange mutagenesis. The insertion.duplication mutagenesis involves the integration a whole plasmid containing a truncated copy of the target gene by homologous recombination with one crossing over. The allelic exchange mutagenesis 
involves homologous recombination with two crossing overs that substitutes the wild.type copy of the target gene by a truncated copy interrupted by a selectable marker gene. No gum mutant was obtained using the allelic exchange strategy; however gumB and gumF mutants were obtained by insertion-duplication mutagenesis strategy. GumD mutant was not obtained, suggesting that the mutation in this gene is lethal to the cell. Analysis of cells and colonies of these mutants growing in solid media and in suspension hasn't reveal any morphological difference to the wild.type strain. The disruption of the gumB and gumF genes does not influenced the adhesion capacity of $X$. fastidiosa to the glass, used as a substrate. Using the reporter gene CAT, wich codes for cloramphenicol acetil transferase enzime confering resistance to cloramphenicol, we verified that glucose has no influence in the expression of this operon at the transcription level. Using this reporter gene, we also identified a transcribed region directed by a non characterized promoter, localized in the antisense strand of the gum operon. A comparison between the soluble protein profile of the mutants and the wild.type strain, obtained by liquid chromatography, showed significative differences, indicating a pleiotropic effect of these mutations. The study of the function of the gumB and gumF genes in the pathogenicity of $X$. fastidiosa was not concluded because we verified recently that the strainm, used to generate the mutants, do not colonize the plants efficiently to induce symptoms in citrus and tobacco plants after mechanical inoculation. 


\section{INTRODUÇÃO}

A Xylella fastidiosa é uma bactéria Gram-negativa, fastidiosa, que vive limitada ao xilema de plantas e é o agente causal de várias doenças de importância econômica como a doença de Pierce em videiras nos Estados Unidos e a Clorose Variegada dos Citros (CVC) no Brasil.

O sintoma mais importante da CVC é a redução e o enrijecimento dos frutos, tornando-os impróprios para o consumo "in natura" ou para a indústria. A citricultura é uma das mais importantes atividades econômicas do estado de São Paulo, gerando mais de 400 mil empregos e milhões de dólares em divisas. A cada ano o número de plantas afetadas pela CVC aumenta, pondo em risco o sustento de várias famílias e prejudicando seriamente a economia do estado e do país. Em decorrência desse panorama, em 1997 iniciou-se um projeto visando sequenciar o genoma da $X$. fastidiosa a fim de desenvolver estratégias para o controle da CVC.

A seqüência genômica de $X$. fastidiosa revelou vários possíveis mecanismos de patogenicidade dessa bactéria, como a produção de toxinas, secreção de enzimas celulolíticas e proteolíticas, seqüestro de íons (principalmente o ferro) e formação de biofilmes que bloqueiam o fluxo de seiva nos vasos xilemáticos.

Foi demonstrado, por microscopia eletrônica, que as células de $X$. fastidiosa que habitam o xilema de plantas sintomáticas estão envolvidas por uma matriz polimérica. Acredita-se que essa matriz polimérica seja secretada pelas células de $X$. fastidiosa e seja constituída por um exopolissacarídeo 
denominado goma fastidiana. Os genes que estariam envolvidos na produção da goma fastidiana estão arranjados em um operon chamado operon gum, cujos genes são homólogos aos do operon responsável pela produção de goma xantana, um exopolissacarídeo sabidamente importante na patogênese de uma outra bactéria fitopatogênica, a Xanthomonas campestris.

A confirmação e elucidação do papel da goma fastidiana na patogênese de $X$. fastidiosa, por meio do uso de mutantes não produtores desse exopolissacarídeo, pode permitir o desenvolvimento de estratégias de controle da CVC mais efetivas e específicas, como por exemplo, o controle biológico pelo uso de microrganismos endofíticos com capacidade de degradação desse exopolissacarídeo.

Sendo assim, os objetivos do presente trabalho foram:

$\checkmark$ Obter mutantes de $X$. fastidiosa para os genes gumB, gumD e gumF;

$\checkmark$ Avaliar a morfologia desses mutantes;

$\checkmark$ Avaliar a influencia da glicose na expressão do operon gum;

$\checkmark$ Avaliar a influência dessas mutações na adesão de $X$. fastidiosa;

$\checkmark$ Comparar o perfil protéico dos mutantes em relação à linhagem selvagem;

$\checkmark$ Avaliar o efeito dessas mutações na patogênese de $X$. fastidiosa por meio de inoculação mecânica em plantas de citros e tabaco. 


\section{REVISÃO DE LITERATURA}

\subsection{A Xylella fastidiosa}

\subsubsection{Generalidades e histórico}

A Xylella fastidiosa é uma bactéria Gram-negativa, fastidiosa, que vive limitada ao xilema (Wells et al. 1987). Atualmente é classificada como membro do filo proteobacteria, sub-divisão gamma, ordem Lysobacteriales, família Lysobacteriaceae e grupo Xanthomonas.

Esta bactéria possui um largo espectro de hospedeiros, sendo patogênica para vários deles (Hopkins, 1989; Purcell, 1996 e 1997). Entre as doenças de importância econômica que causa, a Clorose Variegada dos Citros (CVC) (Rosseti et al. 1990) e o mal de Pierce em videiras ("Pierce's disease") (Davis et al. 1978) são as mais importantes e as mais bem estudadas.

A $X$. fastidiosa tem como vetores cigarrinhas sugadoras de xilema, principalmente as da família Cicadellideae (Purcell et al. 1979), podendo também ser transmitida pelo uso de porta enxertos contaminados.

Os primeiros relatos da literatura sobre $X$. fastidiosa datam de 1973 , quando uma bactéria, semelhante às bactérias da família Rickettsiaceae, foi associada ao mal de Pierce em videira (Gohen et al. 1973 e Hopkins et al. 1973).

Em 1978, Davis e colaboradores, usando um meio para o cultivo da rickettsiaceae Rochalimaea quintana, conseguiu pela primeira vez o isolamento da bactéria associada ao mal de Pierce. Estudos com o DNA desta bactéria 
revelaram uma composição de $\mathrm{G}+\mathrm{C}$ (guanina + citosina) significativamente diferente da composição do grupo das ricketisiaceas, indicando tratar-se então, de uma bactéria pertencente a um grupo taxonômicamente distinto (Kamper et al. 1985; Wells et al. 1987). Em vista disso, a bactéria associada ao mal de Pierce passou a ser chamada de bactéria fastidiosa, Gram-negativa, limitada ao xilema (XLB ou FXLB, do inglês "Fastidious Xylem-Limited Bactéria") (Hopkins et al. 1989).

A comparação entre isolados dessas "bactérias limitadas ao xilema" de diferentes hospedeiros em relação aos seus conteúdos de $G+C$, tamanhos de genoma, composição de ácidos graxos e seqüências do RNA 16S (Wells et al. 1984; Kamper et al. 1985) permitiu concluir que estas bactérias formavam um grupo homogêneo, indistinguível ao nível de espécie. Essa análise também constatou a semelhança desse novo grupo de bactérias com o grupo Xanthomonas, mas constituindo um novo gênero. Sendo assim, Wells (1987) sugeriu o novo gênero Xylella possuindo apenas uma espécie, a Xylella fastidiosa, e definiu suas características como: "células em bastonetes, medindo 0.25-0.35 x 0.9-3.5 $\mu \mathrm{m}$, Gram-negativas, não móveis, aflageladas, oxidase negativa e catalase positiva, aeróbia estritas, não fermentativas, não halofílicas e não pigmentadas, nutricionalmente fastidiosas, temperatura ótima para crescimento entre $26-28{ }^{\circ} \mathrm{C}$, pH ótimo 6,5- 6,9, capazes de hidrolisar gelatina e utilizar piruvato. Esta espécie não fermenta glicose, sendo negativa para indol, $\mathrm{H}_{2} \mathrm{~S}$, lipase, amilase, fosfatase, $\beta$-galactosidase, e tem genoma com conteúdo $\mathrm{G}+\mathrm{C}$ entre 51.0 a 52.4 moles \%".

Até 1993, acreditava-se que a $X$. fastidiosa fosse um patógeno restrito ao continente americano. Entretanto, relatos de sua presença na Ásia (Leu \& Su, 1993) e Europa (Berisha et al. 1998) demonstraram que essa bactéria apresenta uma distribuição mais global. 


\subsubsection{A Xylella fastidiosa e a Clorose Variegada dos Citros (CVC)}

Em junho de 1987, laranjeiras apresentando sintomas ainda desconhecidos foram detectadas no sudoeste do estado de Minas Gerais e no norte do estado de São Paulo (De Negri, 1990). A essa nova doença deu-se o nome de "amarelinho" ou Clorose Variegada dos Citros (CVC). Rosseti et al. (1990) detectou a presença de bactérias associadas ao xilema nas plantas afetadas com a nova doença, e sua morfologia se assemelhava à bactéria $X$. fastidiosa, causadora do mal de Pierce em videiras. Uma análise mais refinada por microscopia eletrônica dessas bactérias limitadas ao xilema, corroborou a hipótese da bactéria $X$. fastidiosa ser o agente causal da CVC.

Em 1993 e 1994, dois grupos independentes (Chang et al. 1993; Hartung et al. 1994) fecharam o postulado de Koch para a bactéria causadora da CVC e constataram, por testes sorológicos, a sua semelhança com a $X$. fastidiosa de outros hospedeiros.

A CVC ataca todas as variedades comerciais de laranja doce (Pêra, Natal, Hamlin, Valência, Folha Murcha, Baianinha e Barão) sobre diferentes porta-enxertos (Limão Cravo, Trifoliata, Tangerinas Cleópatra e Sunki, Laranja Caipira, etc). Entretanto, não foram encontrados sintomas nas tangerinas comerciais (Cravo e Poncan), Tangor Murcote, limões verdadeiros (Siciliano e Eureca) e Lima Ácida Galego, mesmo quando localizados em áreas altamente infectadas (Carvalho, 1996).

Os principais sintomas da CVC são: a) cloroses internervais com pontuações pardas visíveis em ambos os lados do limbo foliar, que podem coalescer e formar áreas necróticas; b) diminuição do porte em plantas severamente afetadas e c) aumento da acidez, diminuição do tamanho e enrijecimento dos frutos, tornando-os sem valor comercial tanto para a produção de suco como para o consumo "in natura" (Quaggio, 1988). Os sintomas em folhas e frutos são mostrados na Figura 1. 

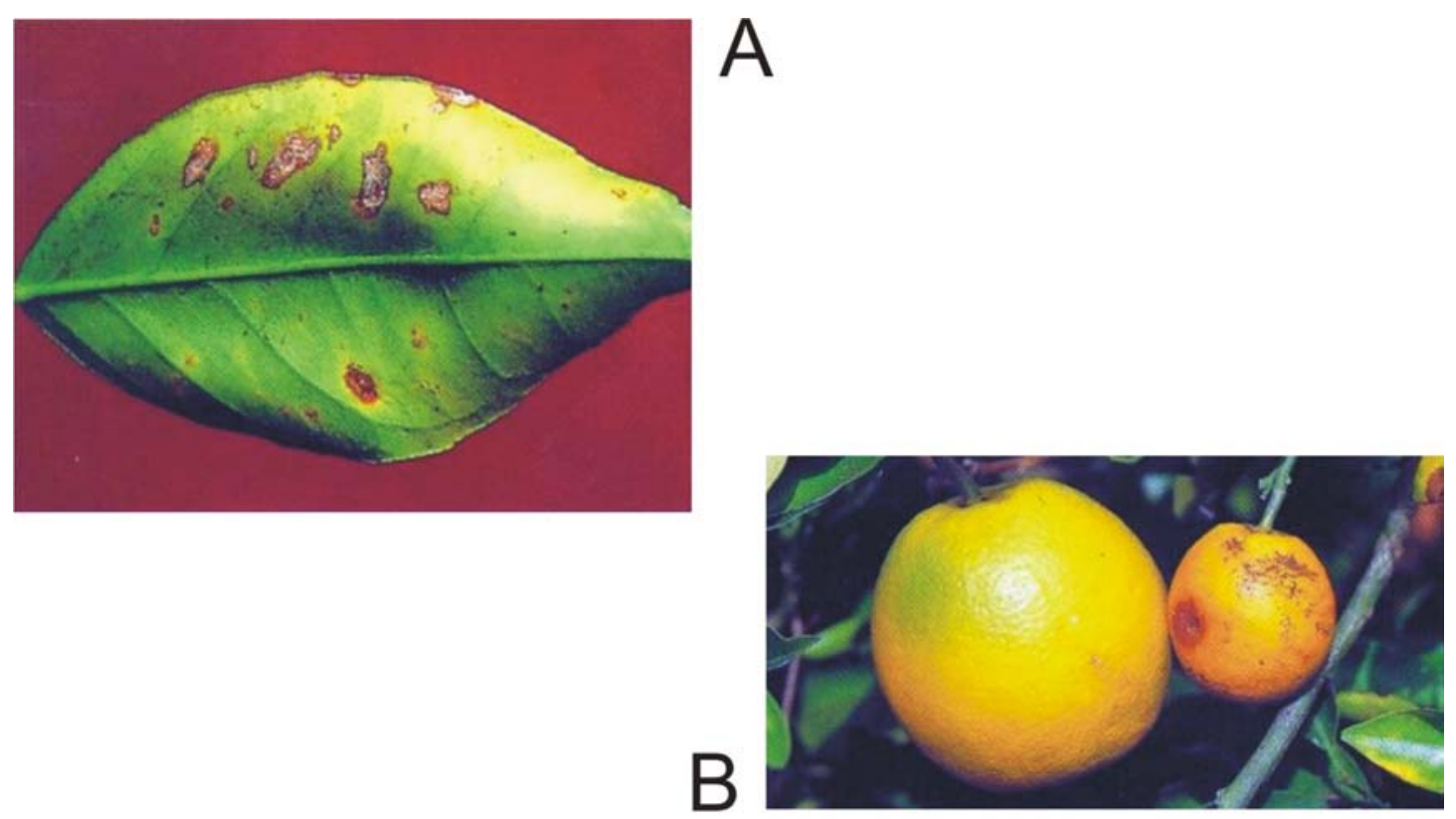

Figura 1 - Sintomas da CVC.

$A=$ Sintomas em folhas

$B=$ Comparação entre um fruto sadio (esquerda) e um afetado (direita)

Assim como no caso dos outros isolados, a $X$. fastidiosa causadora da CVC também é transmitida através de cigarrinhas sugadoras de xilema da família Cicadellidae. As espécies transmissoras mais importantes no Brasil são: Dilobopterus costalimai, Acrogonia terminalis, Bucephalogonia xanthophis e Oncometopia facialis (Lopes et al. 1996; Roberto et al. 1996). A cigarrinha adulta, contaminada inocula a $X$. fastidiosa nas plantas cítricas durante todo o seu ciclo de vida (Purcell, 1997). A bactéria sobrevive no aparelho bucal das cigarrinhas transmissoras e nos vasos do xilema da planta, fechando o ciclo infectante após sua alimentação (Purcell, 1997).

Em um levantamento feito pelo Fundecitrus em 2001, 36,44\% das plantas da região nobre da citricultura brasileira (estado de São Paulo e parte do triangulo mineiro) estavam contaminadas com a CVC. Na região norte do 
estado de São Paulo (região de Bebedouro e Barretos) a incidência atingiu $48,60 \%$.

A citricultura é uma das mais importantes atividades econômicas do estado de São Paulo, gerando mais de 400 mil empregos e milhões de dólares em divisas. A cada ano o número de plantas afetadas pela CVC aumenta, pondo em risco o sustento de várias famílias e prejudicando seriamente a economia do estado e do país. Em decorrência desse panorama, a comunidade científica do estado de São Paulo, financiada pela Fapesp, Fundecitrus e CNPq e incentivada pelos citricultores, iniciou em 1997 um projeto visando sequenciar o genoma da $X$. fastidiosa a fim de desenvolver estratégias para o controle da CVC.

\subsubsection{O genoma da Xylella fastidiosa}

Em julho de 2000, um grupo de pesquisadores brasileiros, publicou a seqüência genômica completa do isolado de $X$. fastidiosa de laranja denominado 9a5c (Simpson et al. 2000). Este foi o primeiro genoma de um patógeno de plantas a ser completamente seqüenciado.

O genoma da $X$. fastidiosa (9a5c) possui um cromossomo com 2.679.305 pares de bases, com um conteúdo de $52,7 \%$ de $G+C$ e dois plasmídeos: um com 51158 pares de bases e $49,6 \%$ de $\mathrm{G}+\mathrm{C}$, chamado pXF51, e outro com 1285 pares de bases e $55,6 \%$ de $G+C$, denominado pXF1.3. Do total de 2884 fases abertas de leitura (ORFs) encontradas, apenas 1314 delas puderam ter a sua função predita a partir de homologia com outros genes de função conhecida (Simpson et al. 2000).

Antes da publicação do genoma, as hipóteses sobre os mecanismos pelos quais a $X$. fastidiosa causava doenças em seus vários hospedeiros eram vagas e pouco exploradas. Hopkins (1989) cita a oclusão dos vasos xilemáticos pelas bactérias, tiloses e gomas; a produção de fitotoxinas e o desbalanço de 
reguladores de crescimento como os possíveis mecanismos de patogenicidade dessa bactéria. Nenhum experimento conseguiu provar nem excluir qualquer dessas teorias.

A partir da seqüência genômica de $X$. fastidiosa, traçou-se todo o perfil básico para a sobrevivência dessa bactéria como o seu metabolismo energético, a síntese de aminoácidos, nucleotídeos e lipídeos e a maquinaria de transcrição, tradução e reparo. Mais importante do que esse perfil, a seqüência genômica de $X$. fastidiosa também permitiu a formulação de hipóteses mais elaboradas sobre os mecanismos de patogenicidade dessa bactéria (Dow et al. 2000; Keen et al. 2000; Lambais et al. 2000; Simpson et al. 2000; da Silva et al. 2001; Meidanis et al. 2002).

Surpreendentemente, não foi encontrado nenhum gene de avirulência (avr) no genoma de $X$. fastidiosa. Devido à diversidade dos genes avr, poderse-ia acreditar que na verdade esses genes estariam "escondidos" entre os genes de função ainda não determinada. Todavia, a ausência dos genes que compõem o sistema de secreção do tipo III, que são extremamente conservados, praticamente descarta essa hipótese, já que os genes avr são dependentes desse sistema. A ausência desses genes pode ser em parte explicada pelo modo de vida e tipo de transmissão da $X$. fastidiosa que não requer a invasão e/ou lise das células do hospedeiro para a sua infecção ou sobrevivência (Dow et al. 2000; Lambais et al. 2000; Simpson et al. 2000;).

Em recente publicação, Bhattacharyya e colaboradores (2002) fizeram uma comparação entre o genoma completo da $X$. fastidiosa de citros (9a5c) com o genoma incompleto de dois outros isolados de amendoeira e de oleandro (Nerium oleander). Apesar de se tratar da mesma espécie, a comparação desses três isolados mostrou a existência de vários genes presentes em apenas um desses isolados ou compartilhados por apenas dois destes. Alguns desses genes estão envolvidos na adesão dessas bactérias e o seu estudo ajudará a desvendar os mecanismos envolvidos na especificidade patógenohospedeiro. 
Os possíveis mecanismos de patogenicidade revelados pela seqüência genômica de $X$. fastidiosa são: produção de toxinas, secreção de enzimas celulolíticas e proteolíticas, seqüestro de íons (principalmente o ferro) e a formação de biofilmes que bloqueiam o fluxo de seiva nos vasos xilemáticos. Associados a estes mecanismos, uma bateria de proteínas estão envolvidas na destoxificação, no bloqueio da entrada de drogas e no descarte ativo de toxinas que entram na célula garantindo sua sobrevivência no hospedeiro, protegendoa de ataques de outros microrganismos que habitam o xilema, ou do próprio hospedeiro.

A $X$. fastidiosa produz um grande arsenal de toxinas, entre elas cinco semelhantes a hemolisinas. Uma delas pertence a uma família não caracterizada e as outras quatro à família das toxinas RTX, que estão largamente distribuídas entre as bactérias Gram-negativas patogênicas. O genoma também revelou a bateria completa de síntese de Colicina- $V$, um polipeptídeo tóxico que age em bactérias sensíveis. Apesar de não possuir as vias completas para a produção de alguns policetídeos, uma importante classe de toxinas bacterianas, a presença de alguns genes relacionados a sua síntese pode indicar que ao menos uma dessas vias é funcional e, os genes para completá-la estariam entre os de função desconhecida (Simpson et al. 2000).

Supõe-se que as funções das enzimas extracelulares (celulases e proteases) produzidas por $X$. fastidiosa sejam a de obtenção de alimentos e a degradação das membranas pits, permitindo a migração da bactéria entre os vasos xilemáticos. A ausência de enzimas pectinolíticas funcionais no genoma de $X$. fastidiosa se deve a sua forma de vida, que não requer a invasão e destruição dos tecidos do hospedeiro (Keen et al. 2000; Simpson et al. 2000). A redução ou ausência desses mecanismos enzimáticos de invasão e degradação pode ser uma forma de evitar os sistemas de defesa da planta, que são disparados quando esta detecta a lise de suas células (Keen et al. 2000).

Alguns íons, especialmente o ferro, magnésio e o manganês são essenciais para a sobrevivência de todos os organismos vivos, pois participam 
como co-fatores de várias enzimas importantes. Em $X$. fastidiosa foram encontrados receptores de membranas para a obtenção de ferro do meio em várias formas além de outras vias que possivelmente estão envolvidas na obtenção de manganês. Acredita-se que a redução da disponibilidade desses íons para a planta contribua significativamente para o aparecimento das lesões nas folhas dos hospedeiros (Simpson et al. 2000; Meidanis et al. 2002).

O bloqueio dos vasos xilemáticos por um biofilme de $X$. fastidiosa é o mecanismo de patogênese mais sugerido e pesquisado. Todavia, os processos que mediam a formação e a manutenção desses biofilmes ainda são desconhecidos. Como será revisado posteriormente, a formação do biofilme envolve a adesão das bactérias a um substrato e a agregação entre elas mesmas, formando uma "comunidade". No genoma de $X$. fastidiosa foram encontradas várias pistas em relação aos participantes desses processos como fímbrias, adesinas, os grupos tiol (SH) da membrana formados pela enzima metionina sulfóxido redutase (Leite et al. 2002) e uma via completa para a síntese de um exopolissacarídeo denominado "goma fastidiana" (da Silva et al. 2001).

Em 1986, Raju e colaboradores detectaram, por microscopia eletrônica, estruturas semelhantes a fímbrias em $X$. fastidiosa colonizando plantas e insetos vetores. Subsequentemente, a seqüência genômica revelou a presença de 26 genes responsáveis pela biogênese e funcionamento de fímbrias do tipo 4. Essas fímbrias se situam no pólo celular e estão presentes em vários patógenos bacterianos mediando a adesão e translocação celular (Brlansky et al. 1983).

As adesinas são proteínas que se localizam na membrana externa das células e promovem, como o próprio nome indica, a adesão a superfícies. As adesinas, até o seqüênciamento do genoma de $X$. fastidiosa, eram associadas apenas a patógenos animais. Sua presença em um fitopatógeno aumenta 0 número de evidências sobre a generalidade dos mecanismos de patogênese 
bacteriana, independentemente da natureza do hospedeiro (Simpson et al. 2000).

Leite et al. (2002), por meio de microanálise por raios-X dos agregados de $X$. fastidiosa in planta e in vitro, propõem que a adesão dessa bactéria ocorre por interações entre as cargas negativas da parede do xilema, e grupos tiol (SH) da membrana externa da bactéria. Esses grupos SH também promoveriam a agregação das bactérias por meio da formação de pontes de dissulfeto entre esses grupos presentes nas membranas de células vizinhas. A detecção de grandes quantidades de íons cálcio e magnésio nos biofilmes sugere a participação desses cátions divalentes nessa interação. Os autores também sugerem que os grupos SH da membrana seriam mantidos pela ação da enzima metionina sulfóxido redutase. O autor sugere também que o início do processo de adesão de $X$. fastidiosa, assim como em Escherichia coli, seja independente da existência da goma fastidiana.

As evidências que incluem a goma fastidiana como um importante fator de virulência de $X$. fastidiosa, por serem o assunto central da presente dissertação, serão discutidas à parte nos próximos tópicos desta revisão.

\subsection{Exopolissacarídeos, biofilmes e seu papel na patogenicidade de bactérias}

Os exopolissacarídeos (EPS) possuem papel fundamental na virulência de várias bactérias fitopatogênicas. Estudos com Agrobacterium, Clavibacter, Erwinia, Pseudomonas e Xanthomonas já demonstram claramente a relação dos EPS com a virulência dessas bactérias, além de permitirem uma análise crítica do papel dessas moléculas na patogênese (Denny, 1995).

Geralmente, os exopolissacarídeos são secretados pelas células bacterianas formando uma camada protetora que possui papel importante tanto na sua sobrevivência quanto na sua virulência. Essa camada pode auxiliar na 
adesão da célula a superfícies, concentrar nutrientes, evitar a dessecação, evitar o contato com o hospedeiro e proteger contra moléculas tóxicas (Denny, 1995). Quando essas bactérias crescem associadas a um substrato, os exopolissacarídeos, outras moléculas e estruturas, como fímbrias e adesinas, formam o esqueleto de uma complexa, organizada e eficiente comunidade bacteriana denominada biofilme.

Os biofilmes bacterianos são uma comunidade estruturada de células, aderidas a um substrato biótico ou não, inseridas em uma matriz polimérica produzida pelas próprias bactérias (Consterton, 1999). O processo de formação dos biofilmes, como citado anteriormente envolve a adesão da bactéria ao substrato e a agregação das células umas as outras. Na adesão há a participação das fímbrias, adesinas (Davey et al. 2000), e de moléculas de DNA que são excretadas para o meio (Whitchurch et al. 2002). A agregação e maturação do biofilme envolvem o aumento do número de células e a deposição de grande quantidade de matriz extracelular (exopolissacarídeos, proteínas, ácidos nucléicos e outras substâncias) para formar o esqueleto do biofilme (Davey et al. 2000).

Essas comunidades podem ser formadas por uma ou várias espécies bacterianas e a sua formação permite maior adaptabilidade e aproveitamento do ambiente. Uma vez dentro do biofilme, as bactérias assumem um comportamento genético e fisiológico distinto daquele de uma vida livre (Davey et al. 2000; Watnick et al. 2000; Whiteley, et al. 2001). Além de fornecer uma proteção contra todo tipo de agente antimicrobiano, os biofilmes, por aproximar as células bacterianas, permitem uma cooperação metabólica que facilita a troca de substratos e a remoção e distribuição de metabólitos (Davey et al. 2000). A proximidade das bactérias dentro de um biofilme também desempenha um papel fundamental na aquisição de novas características genéticas através da transferência horizontal de genes.

Além das vantagens apresentadas pelos biofilmes nos ambientes naturais, a habilidade de formação dessas comunidades pode determinar o 
sucesso ou o fracasso de um patógeno. Além das vantagens nutricionais e de proteção oferecidas pelos biofilmes dentro do hospedeiro, a estreita comunicação que ocorre entre os indivíduos dessas comunidades permite corregular o momento do ataque do patógeno ao hospedeiro (Davey et al. 2000). O mecanismo de sensoriamento do tamanho de populações de bactérias no ambiente denomina-se "quorum sensing".

Em X. fastidiosa, Marques et al. (2002), caracterizaram a formação de biofilmes em vidro e em madeira de isolados de diferentes hospedeiros dessa bactéria. Todos os isolados foram capazes de formar biofilmes apresentando grandes quantidades de matriz extracelular, aparentemente a goma fastidiana. Os autores também descrevem um método inovador que simula uma condição natural, em laboratório (madeira como substrato de adesão) para analisar o biofilme dessas bactérias.

Existem evidências que descartam os exopolissacarídeos como participantes do processo de adesão na formação de biofilmes. Em contrapartida, a manutenção da arquitetura normal desses biofilmes se mostrou totalmente dependente da presença dessas moléculas (Denny, 1995).

\subsection{A goma fastidiana e a patogênese de Xylella fastidiosa}

O genoma de $X$. fastidiosa revelou uma região contendo nove genes, homólogos aos genes do operon responsável pela produção de um exopolissacarídeo chamado goma xantana em Xanthomonas campestris pv campestris (Simpson et al. 2000). Esses nove genes de $X$. fastidiosa também estão arranjados na forma de um operon e ocupam doze kilobases. 


\subsubsection{A goma xantana}

O operon responsável pela produção de goma xantana em $X$. campestris pv campestris, denominado operon gum, é composto por doze genes que ocupam 16 kilobases. Os genes são gumB, gumC, gumD, gumE, gumF, gumG, gumH, guml, gumJ, gumK, gumL e gumM. A goma xantana é um polissacarídeo complexo que consiste de um esqueleto celulósico de (1-4)- $\beta$-D-glicose com agrupamentos laterais de trissacarídeos, nos quais a seqüência manose-ácido glucurônico-manose está ligado a resíduos alternados de glicose. Os resíduos de manose dessas cadeias laterais podem ou não estar modificados por acetilação e piruvatação (Vojnov, 1998).

A síntese de goma xantana acontece em cinco estágios: (i) conversão de açucares simples em nucleotidil-açucares precursores; (ii) montagem das subunidades de pentassacarídeos ligadas a um carreador de poliprenol fosfato; (iii) adição dos grupamentos acetil e piruvil; (iv) polimerização das subunidades e (v) secreção do polímero (lelpi et al. 1993).

Com a utilização de uma coleção de mutantes para os genes gum, Katzen e colaboradores (1998) descreveram a via biossintética da goma xantana e a função de alguns dos doze genes do operon gum (Figura 2). 0 primeiro passo na síntese da goma xantana é catalisado por uma glicosil transferase codificada pelo gene gumD, que liga um precursor nucleotidilglicose ao carreador poliprenol fosfato localizado na membrana. Os genes gumM, gumH, gumK e gumJ, também codificam glicosil transferases que adicionam respectivamente os quatro próximos açucares à cadeia (glicose, manose, ácido glicurônico e manose). Os genes gumF e gumG codificam as acetil trasferases responsáveis pela acetilação da manose na terceira posição e da manose terminal das subunidades, respectivamente. Uma piruvil transferase, codificada pelo gene gumL adiciona o grupamento piruvil à manose terminal. Os 
genes gumB, gumC e gumE são responsáveis pela polimerização e a exportação da goma. O gene gumJ não teve a sua função determinada.

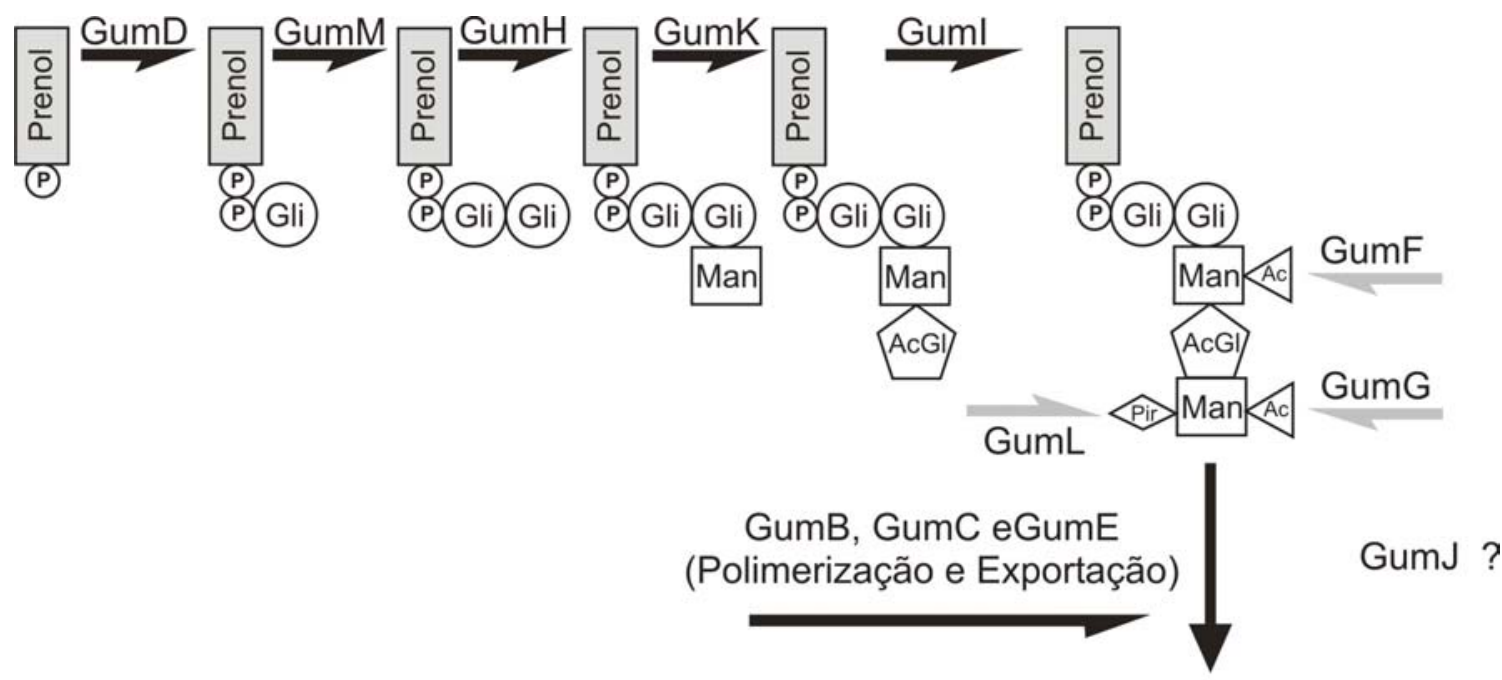

Goma xantana

Figura 2 - Representação esquemática da síntese de goma xantana em Xanthomonas campestris.

Gli= Glicose, Man= Manose, AcGl= Ácido Glicurônico, Ac= Acetil, Pir= Piruvil.

Fonte: Katzen et al. (1998)

A goma xantana é um produto intensivamente utilizado na indústria como emulsificante, estabilizante, espessante e lubrificante. Entretanto, o mais importante é o fato de que este exopolissacarídeo tem um papel importante como fator de virulência. Alguns autores analisaram o efeito de mutantes gum de Xanthomonas na virulência dessa bactéria (Newman et al. 1994; Chou et al. 1997; Katzen et al. 1998). Mutações na maioria dos genes gum resultaram em diminuição da produção de goma xantana, e queda da agressividade. Chou et al. (1997) relaciona a mutação ao gene gumD não apenas a produção de goma xantana e virulência, como também a pigmentação normal das células. Indo de encontro a esses resultados, Katzen et al. (1998) trabalhando com uma coleção 
de mutantes para todos os doze genes gum, não obteve diferenças na pigmentação dessas bactérias.

Mutações nos genes gumB, gumC, gumE, gumJ e gumM de Xanthomonas campestris se mostraram letais nos experimentos de Katzen e colaboradores (2000). Acredita-se que essa letalidade se deva ao acúmulo de certos intermediários tóxicos. Mutantes para esses genes só foram possíveis de ser obtidos quando era utilizada uma linhagem deficiente para a enzima UDPglicose pirofosforilase. Essa enzima é responsável pela formação dos intermediários para a síntese de goma xantana.

Foi demonstrado também que a produção de goma xantana está relacionada a um grupo de genes denominados reguladores de fatores de patogenicidade - rpf (do inglês "regulation of pathogenicity factors"). Mutações nesses genes afetam a produção normal de goma xantana e conseqüentemente a virulência desses mutantes (Tang et al. 1991; Newman et al. 1994; Dow et al. 2000; Chatterjee et al. 2002).

O operon gum é expresso prioritariamente como uma unidade transcricional a partir de um promotor localizado amontante ao gene gumB; todavia, podem existir promotores fracos antes dos genes gumD e gumK (Pollock et al. 1994; Katzen et al. 1996). Vojnov et al. (2001), estudaram a regulação desse operon utilizando uma fusão entre o seu promotor principal e o gene da $\beta$-glicuronidase (GUS). Foi observada uma indução da expressão desse gene em meio de cultura contendo glicose com expressão máxima na fase estacionária da cultura. Quando inoculada em pecíolos, a expressão da fusão se assemelhava ao nível basal de expressão em meio sem glicose e, quando inoculada no mesófilo da folha, a expressão da fusão era semelhante a do meio contendo glicose. Esses resultados foram explicados pela viabilidade de nutrientes no mesófilo e no xilema das plantas e de outros fatores não determinados. 


\subsubsection{A goma fastidiana}

Como mencionado anteriormente, o operon gum de $X$. fastidiosa é composto por nove genes, três a menos do que o operon gum de Xanthomonas campestris. Os genes ausentes são gumG, guml e gumL, que codificam respectivamente uma acetil transferase, uma glicosil transferase e uma piruvil transferase. A Figura 3 mostra uma comparação entre o operon gum de $X$. fastidiosa e o seu homólogo em $X$. campestris. Excetuando-se à falta dessas três enzimas, foram encontrados no genoma de $X$. fastidiosa genes homólogos a todos os outros genes regulatórios e de síntese de açucares precursores envolvidos na síntese de goma xantana (da Silva et al. 2001).

A

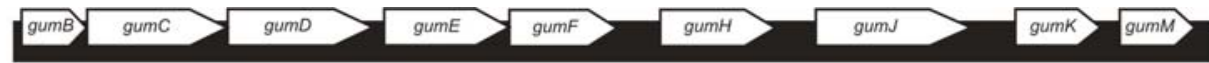

B

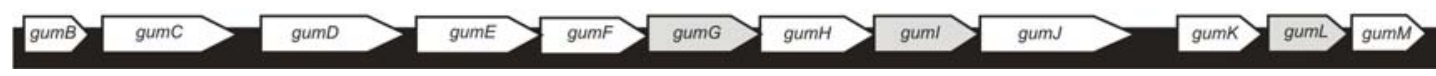

Figura 3 - Comparação dos operons gum de $X$. fastidiosa (A) e $X$. campestris (B).

Nota: O esquema respeita as proporções entre os genes e seus espaçamentos. Em cinza estão representados os genes que estão ausentes em $X$. fastidiosa.

Considerando a similaridade dos nove genes de $X$. fastidiosa com os genes de Xanthomonas campestris e fato de que em ambas as bactérias esses genes estão organizados em operons de estruturas semelhantes, da Silva et al. (2001) descreveram a possível estrutura para a goma fastidiana. Os três genes que estão ausentes em $X$. fastidiosa são responsáveis pela ligação (gum I) e 
modificação (gumG e gumL) do ultimo resíduo de manose da subunidade formadora de goma xantana. Sendo assim, supõe-se que a goma fastidiana seja um politetrâmero (glicose-glicose-manose-ácido glicurônico), enquanto a goma xantana é um polipentâmero (glicose-glicose-manose-ácido glicurônicomanose). Os autores citam também alguns dados que corroboram tal hipótese: (i) Em X. campestris, a inativação de gumL e guml não interfere na taxa de produção de goma xantana na sua forma politetramérica e, (ii) a ação da acetil transferase codificada pelo gene gumF em $X$. campestris ocorre também no estado de trissacarídeo durante a síntese de goma xantana. Uma comparação entre a estrutura das subunidades da goma xantana e a proposta estrutura das subunidades da goma fastidiana é mostrada na Figura 4.

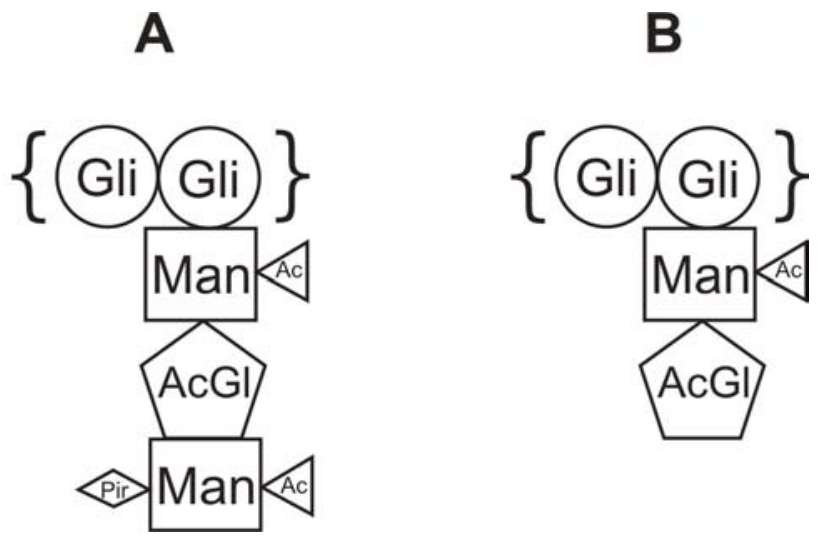

Figura 4 - Comparação das subunidades da goma xantana $(A)$ e da goma fastidiana (B).

Gli= Glicose, Man= Manose, $A c G l=$ Ácido Glicurônico, $A c=$ Acetil, Pir= piruvil Fonte: da Silva et al. (2001)

Utilizando os critérios descritos por Paulsen et al. (1997), que descrevem as características das proteínas que constituem os sistemas de exportação de carboidratos complexos, da Silva et al. (2001) verificaram que as proteínas GumJ, GumC e GumB pertencem a famílias de proteínas de transporte PST 
(transporte específico de polissacarídeos, do inglês "Polysaccharide-Specific Transport"). Apesar da falta de evidências experimentais do papel dessas proteínas em $X$. campestris e em $X$. fastidiosa, tal semelhança concorda ainda mais com o modelo que responsabiliza GumJ, GumC e GumB com o transporte dos exopolissacarídeos produzidos por essas bactérias.

A existência dessas semelhanças entre a bem estudada goma xantana e a goma fastidiana não permite extrapolações seguras em relação ao real papel desse exopolissacarídeo na patogênese e sobrevivência de $X$. fastidiosa. Para tal, torna-se necessária a definição e uso de estratégias que forneçam evidências experimentais sobre a relação goma fastidiana/patogenicidade de $X$. fastidiosa.

\section{4 $O$ uso de mutantes para o estudo de um gene}

Antes do advento das tecnologias de clonagem de genes, a maioria dos genes eram identificados pela associação da alteração de um dado fenótipo a um gene mutado. A obtenção desses mutantes era quase sempre feita por meio de mutagênese randômica, seja por exposição a agentes mutagênicos ou pelo uso de elementos genéticos de inserção aleatória (transposons) (Alberts et al. 2002).

A busca de mutantes específicos dentro de uma coleção de mutantes pode ser extremamente trabalhosa se o fenótipo que o gene de interesse afeta não é tão evidente. O surgimento das técnicas de biologia molecular, e o avanço no seqüenciamento de genomas permitiram uma nova abordagem na elucidação de funções gênicas onde, ao invés de partir de um mutante fenotípico para se buscar o gene envolvido, parte-se da geração de uma mutação em um gene específico para o estudo de seu efeito no fenótipo. Por ser uma abordagem que estuda a relação gene-fenótipo no sentido reverso a 
usada na genética clássica, esta é comumente chamada de genética reversa (Alberts et al. 2002).

Nas bactérias, assim como em alguns eucariotos inferiores, a maneira mais eficiente para a mutação de genes específicos é feira por meio da troca, por recombinação homóloga, da cópia selvagem do gene alvo por uma cópia truncada ou contendo alguma mutação. Esse tipo de mutagênese é chamada genericamente de disrupção gênica por recombinação homóloga.

Os dois principais métodos usados para a disrupção gênica por recombinação homóloga são a mutagênese por inserção-deleção (IDM do inglês "Insertion-duplication Mutagenesis") e a troca alélica (AE do inglês "Alelic Exchange"). A IDM tem sido usada com sucesso em vários organismos como Mycobacterium smegmatis (Bauklard et al. 1996), Neisseria gonorrhoeae (Hamilton et al. 2001), Streptococcus pneumoniae (Lee et al. 1989) e $X$. fastidiosa (Neto et al. 2001; Gaurivaud et al. 2002).

A IDM envolve a recombinação homóloga com uma permuta entre o gene selvagem no cromossomo bacteriano e uma cópia truncada desse gene, clonada em um plasmídeo replicativo ou suicida. Após o evento de permuta, todo o plasmídeo fica inserido no cromossomo bacteriano e o gene alvo sofre uma duplicação (Figura 5).

$A A E$ resulta na troca do gene selvagem por uma cópia interrompida por um marcador de seleção (Figura 6). Essa abordagem envolve a recombinação homóloga com duas permutas. A grande vantagem da troca alélica é o fato dessa estratégia gerar mutantes mais estáveis em comparação a IDM, além de possibilitar a geração de mutações não polares. 

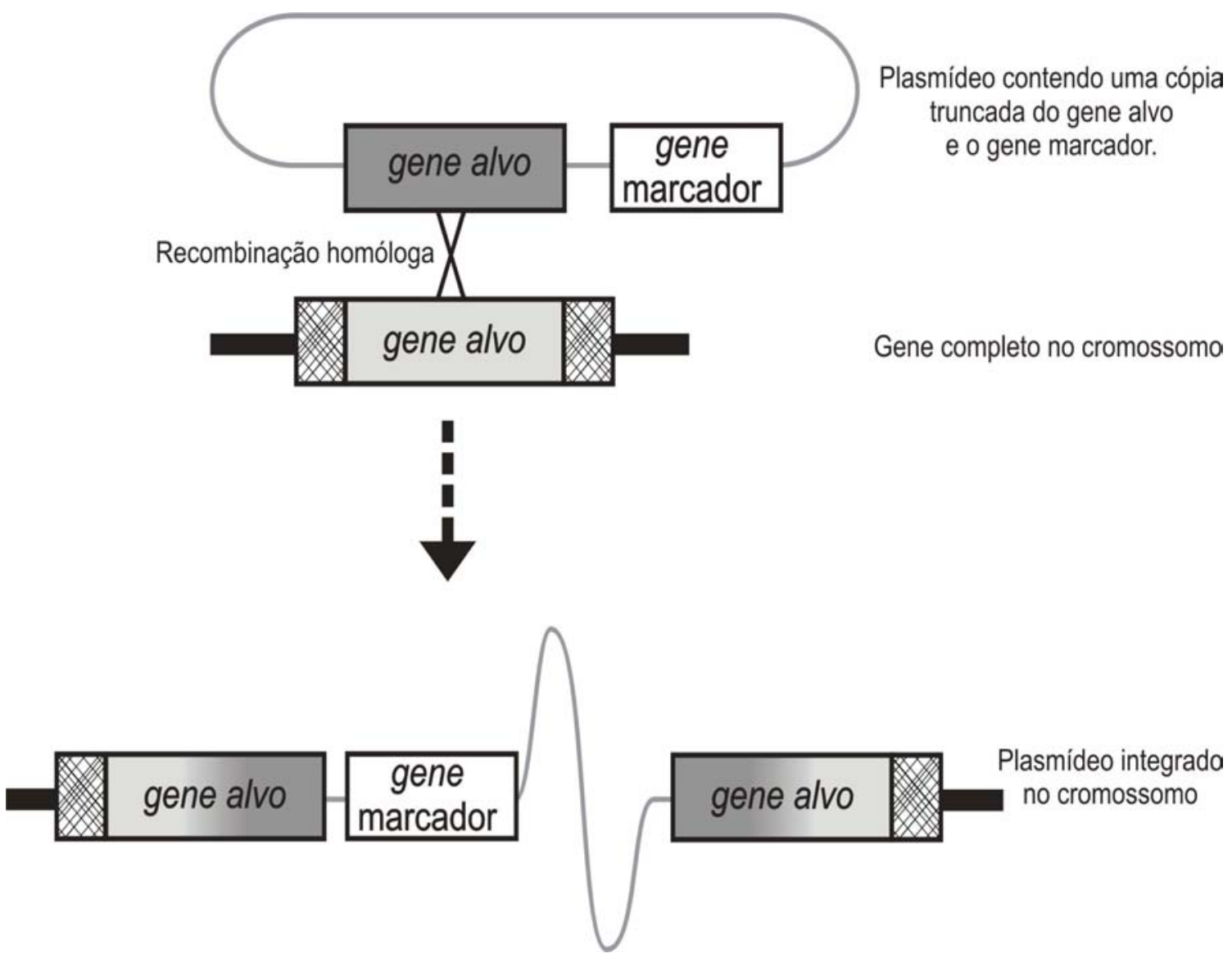

Figura 5 - Esquema mostrando a IDM.

Nota: As regiões hachuradas no gene alvo representam as regiões faltando na cópia presente no plasmídeo. Note a duplicação do gene alvo após a integração e que o promotor desse gene passa a regular a expressão do gene marcador. 


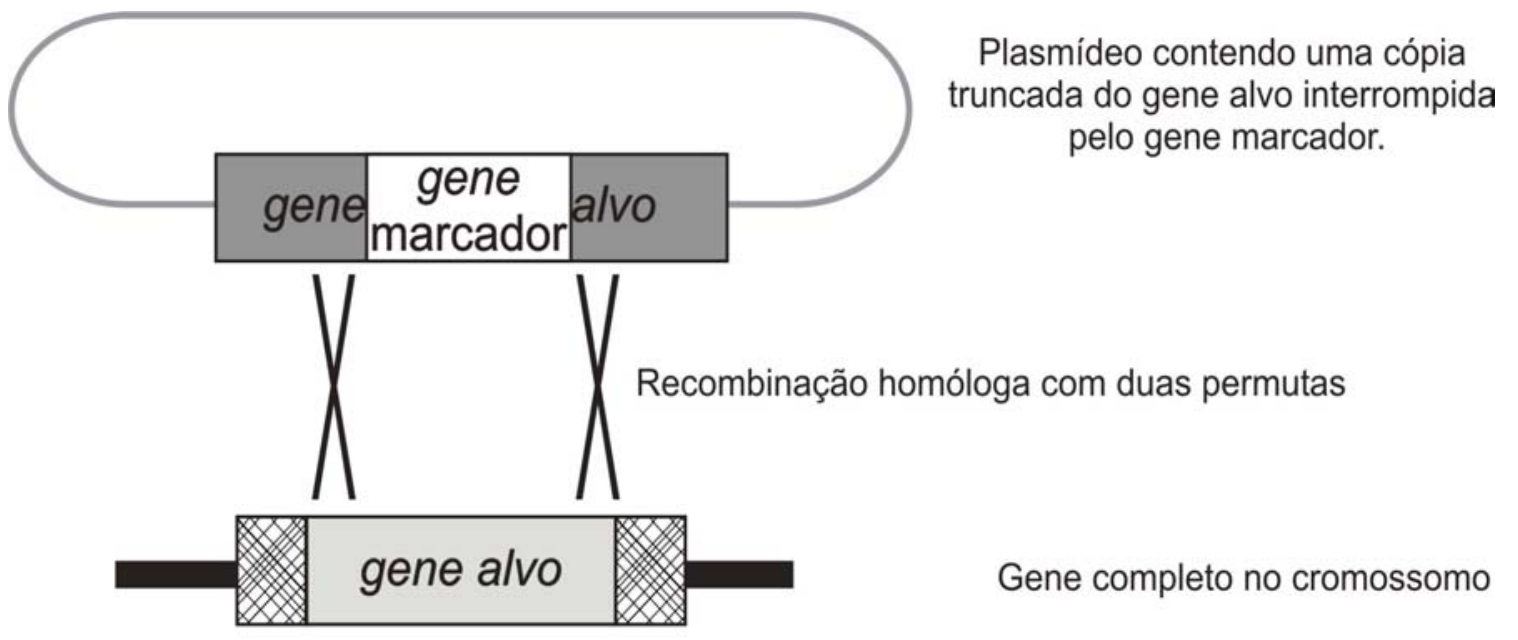

Plasmídeo contendo uma cópia truncada do gene alvo interrompida pelo gene marcador.

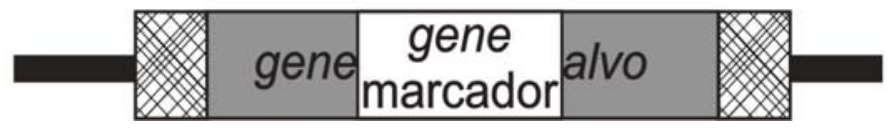

Figura 6 - Esquema mostrando a AE.

Nota: As regiões hachuradas no gene alvo representam as regiões faltando na cópia presente no plasmídeo.

Na mutagênese por inserção-duplicação, uma das cópias do gene alvo sempre continua sob a ação do promotor endógeno e mesmo estando com a sua extremidade 3' deletada, essa cópia pode levar a interpretações errôneas em relação à relação gene/fenótipo. O peptídeo truncado formado pode não ter perdido a sua função original, se o seu sítio ativo estiver localizado na extremidade 5', ter efeito tóxico sobre a célula ou ainda mudar a sua 
especificidade devido a sua alteração estrutural. Para solucionar esse problema, Molnos et al. (2000) desenvolveram um sistema de disrupção gênica para Streptococcus pneumoniae baseado em um sistema natural de degradação protéica presente em várias bactérias, o sistema tmRNA. Esse sistema resgata ribossomos parados no meio da tradução devido a falta de códons de terminação ou de RNAs transportadores, e evita que esses peptídeos incompletos sejam liberados na célula. Para essa tarefa, a molécula de tmRNA possui dupla função: de RNA transportador, carregando uma alanina, e RNA mensageiro, codificando um sinal de degradação para proteases. Ao encontrar um ribossomo parado o tmRNA liga a sua parte transportadora no sítio aceptor do ribossomo e, ao fazer a ligação peptídica o ribossomo é translocado do RNA mensageiro em que está parado para a parte codante do tmRNA. Essa movimentação é chamada de trans-tradução (Keiler et al. 1996; Keiler et al. 2000). Os peptídeos contendo a seqüência codificada pelo tmRNA são então prontamente reconhecidos por proteases que se encarregam de degradar esses peptídeos incompletos.

Molnos et al. (2000) mostraram que o uso dessa seqüência reconhecida por proteases em vetores de disrupção por inserção-duplicação, garante a degradação total do peptídeo truncado formado.

\subsection{Ferramentas para o estudo de Xylella fastidiosa}

\subsubsection{Vetores para transformação e disrupção gênica}

Mesmo depois de ter o seu genoma completamente seqüenciado, nenhuma metodologia havia sido desenvolvida para a manipulação genética de X. fastidiosa. Em 2001 três autores, trabalhando separadamente, publicaram os primeiros avanços no desenvolvimento dessas tecnologias (Guilhabert et al. 2001; Monteiro et al. 2001b; Qin \& Hartung, 2001). 
Monteiro et al. (2001b) desenvolveram vetores contendo a origem de duplicação cromossômica de $X$. fastidiosa (OriC) e o gene que confere resistência a canamicina sob a ação do promotor do gene que codifica o RNA ribossômico $16 \mathrm{~S}$ também de $X$. fastidiosa. Os autores obtiveram sucesso na transformação por eletroporação de três isolados de citros e após alguns repiques dos transformantes, notou-se a integração desses plasmídeos na região promotora do gene do RNA ribossômico $16 \mathrm{~S}$ por recombinação homóloga. Esse trabalho representa o primeiro relato de uma transformação estável em $X$. fastidiosa e a primeira indicação de que a mutação sítio dirigida é possível nessa bactéria.

No mesmo ano, Qin \& Hartung (2001) também conseguiram a transformação de $X$. fastidiosa. Para isso, foi construído um plasmídeo replicativo, denominado $\mathrm{pER} 10$, contendo um fragmento com a origem de replicação de um plasmídeo críptico de $X$. fastidiosa clonado em pUC19.

Guilhalbert et al. (2001) testou a transposição em X. fastidiosa com plasmídeos suicidas contendo os transposons da família Tn5 ou Tn10 e com transpossomos. O transpossomo é a associação de uma transposase hiperativa com um fragmento de DNA linear contendo as seqüências de reconhecimento da transposase e um gene marcador que é inserido nas células por eletroporação. A vantagem do uso dos transpossomos se deve ao fato de que após a inserção do fragmento de DNA pela transposase, essa enzima é degradada evitando a instabilidade genética do mutante devido a outros eventos de transposição. Usando os transposons clonados em plasmídeos suicidas, o autor não obteve sucesso. Todavia, a transposição com os transpossomos se mostrou eficiente por gerar inserções únicas, independentes e estáveis.

Neto et al. (2002) e Gaurivaud et al. (2002) publicaram os primeiros trabalhos demonstrando a disrupção gênica em $X$. fastidiosa. Neto et al. (2002) construíram um vetor contendo o gene que confere resistência a canamicina sob a ação do promotor do gene do RNA ribossômico $16 \mathrm{~S}$ e o plasmídeo 
críptico de $X$. fastidiosa pXF1.3 clonados no plasmídeo comercial pBluescript. Esse vetor se mostrou eficaz na transformação e quando parte do gene $x p s D$ foi clonado nesse plasmídeo, observou-se a integração de todo o plasmídeo nesse gene por recombinação homóloga com uma permuta. A proteína XpsD faz parte do sistema de secreção do tipo II, um sistema de secreção genérico.

Gaurivaud et al. (2002) utilizaram vetores contendo a origem de duplicação cromossômica de $X$. fastidiosa (OriC), baseados no trabalho de Monteiro et al. (2001b), para a disrupção dos genes bga e cvaB. A linhagem de $X$. fastidiosa utilizada nos experimentos foi a linhagem J1a12. Por conferir um fenótipo de fácil visualização, o gene bga, que codifica a enzima $\beta$ galactosidase, foi usado como modelo para a disrupção pela estratégia de mutagênese por inserção-deleção (IDM). A utilização desse vetor para essa estratégia acarreta na existência de dois possíveis sítios de integração, o gene alvo e a origem de duplicação OriC. O efeito da relação do tamanho da cópia truncada do gene alvo e do tamanho da OriC na integração do plasmídeo também foi avaliada. Observou-se uma preferência de integração no gene alvo para fragmentos iguais ou maiores do que a OriC. A utilização do gene Cloranfenicol Acetil Transferase (CAT), que confere resistência a cloranfenicol, como um gene repórter de integração também foi testado. Para tal, uma cópia do gene CAT, sem promotor, foi clonada em fusão de transcrição com a cópia truncada do gene cvaB. O gene cvaB apresenta homologia com um componente do sistema $A B C$ de transporte de colicina $V$, possivelmente envolvido na patogenicidade dessa bactéria. Essa configuração garante que o gene CAT seja expresso apenas quando integrado no genoma e sob o controle do promotor do gene $c v a B$. A seleção de mutantes para o gene $c v a B$ usando culturas contendo o antibiótico cloranfenicol se mostrou eficiente, impedindo a "contaminação" por bactérias nas quais a integração não tenha ocorrido ou tenha ocorrido na OriC e demonstrando que esse gene é expresso nas condições experimentais usadas (cultivo em meio PW). 
Gaurivaud et al. (2002) também obtiveram mutantes por troca alélica (AE). Para tal, uma cópia truncada do gene bga interrompida pelo gene que confere resistência a canamicina, foi clonada em plasmídeos suicidas e plasmídeos contendo origem de duplicação cromossômica OriC. Não foi possível a obtenção de transformantes com o uso dos plasmídeos suicidas. Para os plasmídeos contendo a OriC, observou-se a integração com duas permutas na nona passagem.

\subsection{2 $O$ uso de hospedeiros alternativos para o estudo da patogênese de Xylella fastidiosa}

Um dos grandes problemas enfrentados para o estudo dos mecanismos da interação $X$. fastidiosa-hospedeiro foi a utilização de hospedeiros experimentais de resposta rápida para testes de patogenicidade. A utilização de plantas de citros para tais testes, apesar de ideal, se mostra inapropriada, pois em citros há demora de 6 meses a 1 ano para o desenvolvimento de sintomas em plantas inoculadas (Hartung et al. 1994).

Lopes et al. (2000) usaram com sucesso plantas de tabaco (Nicotiana tabacum) como hospedeiro experimental de $X$. fastidiosa. Todas as plantas inoculadas mostraram sintomas inequívocos nas folhas oito semanas após a inoculação. Os sintomas se caracterizaram por lesões pequenas e escuras, que apareceram inicialmente na margem de folhas mais velhas. Análise das plantas sintomáticas por microscopia eletrônica de varredura mostrou a presença de $X$. fastidiosa restrita ao xilema.

Monteiro et al. (2001a) mostraram que a vinca (Catharanthus roseus) também pode ser usada como um hospedeiro experimental para testes de patogenicidade de $X$. fastidiosa. Os autores também testaram a influência da repicagem continuada em meio de cultura na patogênese dessa bactéria. Com dois meses após a inoculação, notou-se uma maior porcentagem na incidência 
de sintomas nas plantas de baixo repique, confirmando a suspeita de que as bactérias reduzem sua virulência com o cultivo continuado em laboratório. Com quatro meses todas as plantas apresentavam sintomas, indicando que não houve perda de patogenicidade devido aos repiques. Os sintomas observados inicialmente foram deformação das folhas jovens, e redução no porte das plantas. Houve também o aparecimento de zonas cloróticas marginais e ao longo das nervuras das folhas. Microscopia de fluorescência mostrou a presença de bactérias habitando o xilema das plantas inoculadas. 


\section{Material e Métodos}

\subsection{Material}

\subsubsection{Linhagens bacterianas e condições de cultivo}

Foi utilizada a linhagem J1a12 de Xylella fastidiosa (Monteiro et al. 2001b). A linhagem J1a12 foi isolada de plantas de citros, sintomáticas para CVC, coletadas da região de Jales, estado de São Paulo. Os cultivos de Xylella fastidiosa foram feitos em meio PW ou PWG (descritos no item 3.1.3), suplementados ou não com antibióticos, a $28^{\circ} \mathrm{C}$ sob agitação constante de 100 rotações por minuto (rpm).

Para clonagem e propagação de plasmídeos foi utilizada a linhagem de Escherichia coli XL1-Blue (recA1 endA1 gyrA96 thi-1 hsdR17 supE44 relA1 lac [F' proAB lac/9Z.M15 Tn10 (Tet')]). Os cultivos dessa bactéria foram feitos em

meio LB (descrito no item 3.1.3), suplementado com tetraciclina e o antibiótico que o plasmídeo inserido confere resistência, a $37^{\circ} \mathrm{C}$ sob agitação constante de 200rpm. 


\subsubsection{Enzimas de restrição, enzimas de modificação e kits para biologia molecular}

As enzimas de restrição, modificação e a taq DNA polimerase foram adquiridas da Invitrogem/Life technologies.

Os kits para biologia molecular utilizados e seus respectivos fabricantes foram:

$\checkmark$ Kit para clonagem de produtos de PCR, "pGEM- ${ }^{\circledR}$ System" (Stratagene);

$\checkmark$ Kit para purificação de produtos de PCR, "Concert PCR Purification System" (Life technologies) e de bandas de gel, "Concert Gel Band Purification System" (Life technologies) e;

$\checkmark$ Kit para marcação de sondas e revelação de Southern blot, "ECL Direct Nucleic Acid Labelling and Detection System" (Amershan Pharmacia).

\subsubsection{Meios de cultura}

Meio LB - “LuRIA-BERTANi”'(SAMBRoOK ET AL. 1989)

Meio utilizado para o cultivo de $E$. coli.

Extrato de levedura

$\mathrm{NaCl}$

Triptona

Àgua destilada
$5 g$

$10 \mathrm{~g}$

$10 \mathrm{~g}$

$1000 \mathrm{~mL}$ (q.s.p.) 
Todos os ingredientes foram adicionados à água destilada, $\mathrm{o} \mathrm{pH}$ foi acertado para 7,0 e autoclavou-se por $20 \mathrm{~min}$. Para o preparo de meio sólido, adicionar $15 \mathrm{~g} / \mathrm{l}$ de ágar antes da autoclavagem.

Meio PW - "Periwinkle Wilt" (Davis et al. 1978)

Meio utilizado para o cultivo de Xylella fastidiosa.

Peptona de soja

Triptona

$\mathrm{K}_{2} \mathrm{HPO}_{4}$

$\mathrm{KH}_{2} \mathrm{PO}_{4}$

$\mathrm{MgSO}_{4} .7 \mathrm{H}_{2} \mathrm{O}$

Hemina clorada $(0,1 \%)$

Vermelho de Fenol $(0,2 \%)$

Água destilada
$4,0 \mathrm{~g}$

$1,0 \mathrm{~g}$

$1,2 \mathrm{~g}$

$1,0 \mathrm{~g}$

$0,4 \mathrm{~g}$

$10 \mathrm{~mL}$

$10 \mathrm{~mL}$

$840 \mathrm{~mL}$ (q.s.p.)

$\mathrm{O}$ pH do meio foi acertado para 6,8 e autoclavado por 20 minutos. Após a autoclavagem, com o meio resfriado por volta de $65^{\circ} \mathrm{C}$, adicionou-se ao meio sob condições estéreis $100 \mathrm{ml}$ de L-Glutamina (4\%) e $60 \mathrm{ml}$ de Soro Albumina Bovina V (BSA) (10\%)

As soluções de Glutamina e BSA são esterilizados por filtração (filtro de 0,2 $\mu \mathrm{m}$ ) antes de serem adicionados ao meio.

Para o preparo de meio sólido, adicionou-se $12 \mathrm{~g} / \mathrm{l}$ de ágar antes da autoclavagem. Para preparo do meio PWG (PW + $1 \%$ de glicose) adicionou-se $20 \mathrm{ml}$ de uma solução de glicose $50 \%$ previamente esterilizada por filtração.

\subsubsection{Soluções}

\section{Solução de Glutamina 4 \%}

Glutamina 
Água destilada

$100 \mathrm{~mL}$

Solução de Soro albumina bovina $10 \%$

Soro albumina bovina

$10,0 \mathrm{~g}$

Água destilada

$100 \mathrm{~mL}$

Solução de Hemina clorada $0,1 \%$

Hemina clorada

$0,1 \mathrm{~g}$

$\mathrm{NaOH}$

$0,2 \mathrm{~g}$

Água destilada

$100 \mathrm{~mL}$

Solução de Vermelho de fenol $0,2 \%$

Vermelho de fenol

$0,2 \mathrm{~g}$

Água destilada

$100 \mathrm{~mL}$

\section{Tampão TE}

Tris-HCl $1 \mathrm{M} \mathrm{pH} \mathrm{7,5}$

$10 \mathrm{~mL}$

EDTA 0,5 M pH 8,0

$2 \mathrm{~mL}$

Água destilada

$1000 \mathrm{~mL}$ q.s.p.

SDS $10 \%$

SDS

$10,0 \mathrm{~g}$

Água destilada

$100 \mathrm{~mL}$ (q.s.p.) 
A solução foi aquecida até $68^{\circ} \mathrm{C}$ para dissolução e o volume foi ajustado para $100 \mathrm{~mL}$.

\section{Solução de RNase}

RNAse

$10,0 \mathrm{mg} / \mathrm{mL}$

Tris-HCl pH 8,0

$10 \mathrm{mM}$

$\mathrm{NaCl}$

$15 \mathrm{mM}$

Proteinase K

Proteinase $\mathrm{K}$

Água Milli-Q

$2,0 \mathrm{mg}$

$100 \mu \mathrm{L}$

$\mathrm{NaCl} 5 \mathrm{M}$

$\mathrm{NaCl}$

$29,2 \mathrm{~g}$

Água destilada

$80 \mathrm{~mL}$

CTAB $10 \%$

Tris- $\mathrm{HCl}$

$2,42 \mathrm{~g}$

$\mathrm{NaCl}$

$8,20 \mathrm{~g}$

EDTA

$0,74 \mathrm{~g}$

CTAB

$2,00 \mathrm{~g}$

Água destilada

$80 \mathrm{~mL}$

A solução foi aquecida para melhor dissolução.

Solução estoque de brometo de etídio 1,0 \%

Brometo de etídio

$1 \mathrm{~g}$

Água destilada

$100 \mathrm{~mL}$ 
O brometo de etídeo foi dissolvido em água destilada durante uma hora com agitação e em seguida estocado a $4^{\circ} \mathrm{C}$ em frasco ambar.

\section{Solução Tris-HCI 1 M}

Tris base

$121,1 \mathrm{~g}$

Água Milli-Q

$800 \mathrm{~mL}$

$\mathrm{O} \mathrm{pH}$ foi ajustado para $7,5 \mathrm{com} \mathrm{HCl}$ concentrado e completou-se o volume para 1000 $\mathrm{mL}$ com água Milli-Q.

\section{Solução de EDTA 0,5 M (pH 7,5)}

EDTA. $2 \mathrm{H}_{2} \mathrm{O}$

$186,1 \mathrm{~g}$

Água destilada

$800 \mathrm{~mL}$

Ajustar o pH para 7,5 com $\mathrm{NaOH}$ sólido. Após a dissolução completa do EDTA, completar o volume para $1000 \mathrm{~mL}$ com água destilada.

\section{Tampão TAE 50X}

Tris base

$242 \mathrm{~g}$

Ácido acético glacial

$57 \mathrm{~mL}$

EDTA 0,5 M (pH 8,0)

$100 \mathrm{~mL}$

Água destilada

$1000 \mathrm{ml}$ (q.s.p.)

Citrato de sódio

$77 \mathrm{~g}$

Cloreto de sódio

$175 \mathrm{~g}$

Água destilada

$1000 \mathrm{ml}$ (q.s.p.)

SSC 20X 


\subsubsection{Oligonucletídeos}

A tabela 1 apresenta os oligonucleotídeos usados no presente trabalho:

Tabela 1. Oligonucleotídeos utilizados.

\begin{tabular}{|c|c|c|}
\hline Nome & Seqüência & Sítios de restrição \\
\hline \multirow[t]{2}{*}{ Tm1 } & GATCCTGCAGCTGCCAACGAAGACAACTTCGCTGT & \\
\hline & AGCCGCTTAAGCATGCATGTC & Pst I e Sph I \\
\hline \multirow[t]{2}{*}{ Tm2 } & GACATGCATGCTTAAGCGGCTACAGCGAAGTTGTC & \\
\hline & TTCGTTGGCAGCTGCAGGATC & Pst I e Sph I \\
\hline AMPF & CATATGAAAAAGGAAGAGTATGAGTATTCA & Nde I \\
\hline AMPR & CATATGCAGTTACCAATGCTTAATCAGTGA & Nde I \\
\hline CATF & CATATGGAGAAAAAAATCACTGGATATACC & Nde I \\
\hline CATR & CATATGTTACGCCCCGCCCTGC & Nde I \\
\hline \multirow[t]{2}{*}{ GBF } & TCCAAGTCGACGATCTGGAG & Taq I, Acc I e Hinc \\
\hline & & $\|$ \\
\hline GBR & GAGATCTGCAGGATAGATCTC & Pst I \\
\hline GDF & CGTTACTGTATACGGTGATTTG & Acc I \\
\hline GDR & CCAACTGCAGTGATACGAC & Pst I \\
\hline GFF & TATGTGCCAGTACGAGGAGGGACATTAGC & - \\
\hline GFR & CTGCAGCCAGCCCATTGTACCAATGACCATTG & Pst I \\
\hline
\end{tabular}

\subsubsection{Plasmídeos}


Os plasmídeos pBS e pUC4K foram adquiridos dos seus fabricantes Stratagene e Pharmacia, respectivamente.

O plasmídeo pKPFCAT foi doado pelo Dr. Joel Renaudin (INRA, Bourdeaux, França)

O plasmídeo pK36dnaB bi fornecido por Monteiro et al. (2001b).

O plasmídeo pGEM-T faz parte do kit "pGEM-T system" (Stratagene).

\subsection{Métodos}

3.2.1 Enzimas de restrição e modificação, PCRs e manipulação de vetores em $E$. coli

Todas as enzimas de restrição e modificação foram usadas de acordo com as instruções do fabricante.

As células de E.coli foram transformadas por eletroporação usando-se cubetas de $0,2 \mathrm{~cm}, 2,5 \mathrm{kV}$ de potência, $200 \Omega$ de resistência e um campo de 25 $\mu \mathrm{F}$. As células competentes foram preparadas seguindo-se o protocolo descrito por Sambrook et al. (1989).

As extrações de plasmídeos foram feitas pelo método da lise alcalina descrito por Sambrook et al. (1989).

Excetuando-se nos casos explicitados, os PCR foram feitos usando-se 2,5U da enzima Taq DNA polimerase, com uma concentração de $2 \mathrm{mM}$ de $\mathrm{MgCl}_{2}, 0,2 \mathrm{mM}$ de cada desoxinucleotídeo, $1 \mathrm{mM}$ de cada oligonucleotídeo e $1 \mathrm{X}$ do tampão para PCR.

\subsubsection{Dimerização dos oligonucleotídeos Tm1 e Tm2}

Os oligonucleotídeos Tm1 e Tm2 são complementares e sua dimerização gera um fragmento de DNA contendo a sequência codante do tmRNA de $X$. fastidiosa. Para a sua dimerização, uma solução contendo $1 \mu \mathrm{g}$ de cada um 
desses oligonucleotídeos foi aquecida a $95^{\circ} \mathrm{C}$ e resfriada vagarosamente até $25^{\circ}$ C. A redução lenta da temperatura garante a formação correta dos dímeros.

\subsubsection{Preparação de células competentes e transformação de Xylella fastidiosa}

Uma colônia isolada de $X$. fastidiosa foi utilizada e transferida para $2 \mathrm{ml}$ de meio PW (sem $\mathrm{MgSO}_{4},+0,1 \%$ histidina e $+0,5 \%$ glicose) incubando-se por 5 dias. Dessa cultura foram utilizadas $0,3 \mathrm{ml}$ que foram transferidos para 30 $\mathrm{ml}$ do mesmo meio e, nas mesmas condições a cultura foi crescida por mais 4 5 dias. Após esse período, a cultura foi transferida para tubos de polipropileno e centrifugada ( $15 \mathrm{~min}, 2600 \mathrm{~g}, 4^{\circ} \mathrm{C}$ ). As células foram então lavadas duas vezes com $30 \mathrm{ml}$ de água ultrapura (Milli Q; Millipore), esterilizada e gelada e depois lavadas por mais duas vezes com uma solução de glicerol $10 \%$ esterilizada. Após as lavagens, as células foram ressuspendidas em $300 \mu \mathrm{l}$ de glicerol 10\% ficando prontas para a transformação.

Para a transformação, adicionou-se à uma alíquota de $100 \mu$ l de células, 5 a $10 \mu \mathrm{g}$ de plasmídeo e essa mistura de células e DNA foram transferidas para uma cubeta de eletroporação de $0,2 \mathrm{~cm}$. As células foram eletroporadas usando-se $2,5 \mathrm{kV}, 200 \Omega$ e $25 \mu \mathrm{F}$ gerando um pulso de aproximadamente $5 \mathrm{~ms}$. Adicionou-se $1 \mathrm{ml}$ de PW líquido æ̀ células eletroporadas que foram cultivadas por 12 horas a $29^{\circ} \mathrm{C}$. Alíquotas de $250 \mu l$ dessas células foram semeadas em meio PW sólido contendo $10 \mu \mathrm{g} / \mathrm{ml}$ de ampicilina ou $5 \mu \mathrm{g} / \mathrm{ml}$ de canamicina. As placas foram incubadas a $29^{\circ} \mathrm{C}$ até o surgimento das primeiras colônias.

\subsubsection{Repiques dos transformantes}


Foram selecionadas aleatoriamente 5 colônias de cada transformante que foram transferidas para tubos de $10 \mathrm{ml}$ contendo $2 \mathrm{ml}$ de meio $\mathrm{PW}$ suplementado com $5 \mu \mathrm{g} / \mathrm{ml}$ de canamicina. Os tubos foram mantidos a $28^{\circ} \mathrm{C}$ sob agitação constante de 100rpm. Repiques em uma diluição de 1/10 foram feitos a cada 7 dias. Cada repique (ou passagem) corresponde a aproximadamente 3,25 gerações de $X$. fastidiosa.

A partir da sexta passagem, iniciou-se a verificação da integração dos plasmídeos por Southern blot.

\subsubsection{Avaliação da integração por Southern blot e obtenção das culturas puras}

\subsubsection{Extração de DNA}

A extração de DNA de $X$. fastidiosa para os Southern blots foi feita da seguinte forma:

Culturas de $30 \mathrm{ml}$ de meio PW crescidas por uma semana foram centrifugadas por 15 minutos a $9700 \mathrm{~g}$ e seu sobrenadante descartado. $\mathrm{O}$ precipitado de células formado foi ressuspendido em $567 \mu \mathrm{l}$ de TE e em seguida adicionou-se $30 \mu \mathrm{l}$ de SDS, $3 \mu \mathrm{l}$ de proteinase $\mathrm{K}$ e $5 \mu \mathrm{l}$ de RNase. Após vigorosa agitação, a mistura foi incubada a $37^{\circ} \mathrm{C}$ durante 1 hora. Após a incubação adicionou-se $100 \mu \mathrm{l}$ de $\mathrm{NaCl} 5 \mathrm{M}$ e depois de bem homogeneizado adicionou-se $80 \mu \mathrm{l}$ de CTAB 10\%. Incubou-se então a amostra por mais 10 minutos a $65^{\circ} \mathrm{C}$. Após esse período, adicionou-se $800 \mu \mathrm{l}$ de uma solução de clorofórmio/álcool isoamílico. A solução foi homogeneizada por inversão dos tubos e centrifugada a $9700 \mathrm{~g}$ por 10 minutos. Removeu-se a fase superior do centrifugado (fase aquosa) para um novo tubo, evitando-se tocar na interface sobrenadante precipitado formada. O DNA foi então precipitado adicionando-se 0,6 volumes de isopropanol e homogeneizando-o por inversões do tubo. O tubo foi então centrifugado por 20 minutos a $4^{\circ} \mathrm{C}$ e o DNA precipitado foi a seguir 
lavado com etanol 70\%. Deixou-se secar o DNA ao ar e este foi ressuspendido em $40 \mu l$ de água Milli-Q estérilizada

\subsubsection{Southern blots}

Para os Southern blots, usaram-se as soluções e seguiu-se o protocolo descrito do Kit "ECL Direct Nucleic Acid Labelling and Detection System".

Os DNAs genômicos foram clivados por 12 hs e separados em gel de agarose 1\%. O DNA foi transferido para a membrana por capilaridade, por 12 horas, usando-se $\mathrm{NaOH}$ como tampão de transferência (transferência alcalina).

A membrana contendo o DNA foi lavada por 5 minutos sob agitação em $100 \mathrm{ml}$ de SSC $2 \mathrm{X}$ e pré hibridizada sob agitação por duas horas a $45^{\circ} \mathrm{C} \mathrm{em}$ $25 \mathrm{ml}$ da solução de pré-hibridação ( $5 \%$ blocking reagent; $0,5 \mathrm{M} \mathrm{NaCl}$ em $25 \mathrm{ml}$ de "gold buffer" - para membranas de aproximadamente $150 \mathrm{~cm}^{2}$ ).

A marcação da sonda foi feita juntando-se $15 \mu \mathrm{l}$ da solução de glutaraldeído, $15 \mu \mathrm{l}$ da "labeling solution" e $15 \mu \mathrm{l}$ do DNA a ser marcado (100ng), incubando-se a $37^{\circ} \mathrm{C}$ por 15 minutos.

Após a pré-hibridação, a sonda marcada foi adicionada a solução de préhibridização e deixada hibridizando por 12 horas.

Passado o período de hibridação, foram feitas duas lavagens de 20 minutos a $45^{\circ} \mathrm{C}$ com $30 \mathrm{ml}$ do tampão de estringência $(0,1 \mathrm{X}$ SSC, $0,04 \%$ SDS e $5 \mathrm{M}$ uréia) e mais duas de 5 minutos a temperatura ambiente com SSC 2X.

O sinal da sonda foi obtido adicionando-se $10 \mathrm{ml}$ da solução de detecção (5 $\mathrm{ml}$ da solução $A+5 \mathrm{ml}$ da solução $B$ ). $O$ sinal foi captado por meio da exposição das membranas a filmes radiográficos.

\subsubsection{Obtenção de culturas puras}


Para a obtenção de culturas puras dos mutantes, os clones nos quais a integração havia sido detectada foram cultivadas por três dias em meio PW líquido pH 6,2, e semeadas em meio PW sólido. Cinco colônias isoladas de cada placa foram a seguir cultivadas por mais três dias em PW pH 6,2 e novamente semeadas em meio PW sólido. Após mais um ciclo de cultivo PW $\mathrm{pH} \mathrm{6,2} \mathrm{/} \mathrm{semeadura} \mathrm{em} \mathrm{meio} \mathrm{PW,} \mathrm{as} \mathrm{culturas} \mathrm{foram} \mathrm{consideradas} \mathrm{puras,} \mathrm{o} \mathrm{que}$ foi confirmado novamente por Southern blot.

\subsubsection{Análise da expressão do gene repórter CAT}

Uma diluição 1/20 de culturas em fase exponencial (7 dias) foi dividida, em meios PW e PWG, em alíquotas de $3 \mathrm{ml}$ suplementadas com cloranfenicol nas concentrações $0,2,3,4,5$ e $6 \mu \mathrm{g} / \mathrm{ml}$, no caso do experimento com o mutante gumB; ou 0, 2, 6, 8, 10 e $12 \mu \mathrm{g} / \mathrm{ml}$ no caso do experimento com o mutante gumF. Após seis dias de crescimento as densidades ópticas das culturas foram medidas por espectrofotometria $\left(\mathrm{ABS}_{590 \mathrm{~nm}}\right)$.

\subsubsection{Análise morfológica dos mutantes}

Para a análise da morfologia por microscopia óptica dos mutantes foi feito um esfregaço corado com azul de metileno colocando-se em uma lâmina de vidro uma gota da cultura dos mutantes e da linhagem selvagem com 10 dias de crescimento secando-se ao ar por alguns minutos. Os esfregaços foram fixados por aquecimento por 3 vezes em chama do bico de Bunsen. $O$ esfregaço foi coberto com gotas de uma solução de azul de metileno (15g/l azul de metileno; $50 \mathrm{~g} / \mathrm{l}$ fenol fundido e $10 \%$ etanol) por cinco minutos e em

seguida lavou-se com água destilada. As células foram observadas em microscopia óptica de campo claro no aumento de 1000x. 
A análise da morfologia das colônias dos mutantes foi feita a partir de culturas crescidas em placas de meio PW observadas em estereomicroscópio no aumento de 4x com luz incidente e/ou com transiluminação.

\subsubsection{Ensaio de adesão em vidro}

Para avaliar a capacidade de $X$. fastidiosa se aderir ao vidro foi utilizada uma modificação do protocolo descrito para Pseudomonas fluorescens (Kjaergaard et al. 2000) e Salmonela enteritidis (Solano et al. 1998).

Alíquotas de $3 \mathrm{ml}$ em uma diluição de 1/10 de uma cultura em fase exponencial foram crescidas em meio PW, com e sem glicose (1\%), sobre agitação constante por 6 dias. As células em suspensão foram então retiradas cuidadosamente dos tubos de cultura e sua densidade óptica medida a 590nm. As células aderidas ao vidro foram então coradas com cristal violeta $0,1 \%$ e os tubos foram cuidadosamente lavados com água. O cristal violeta aderido nas células foi então dissolvido usando-se uma solução de etanol/acetona (20:80) e sua densidade óptica medida a $590 \mathrm{~nm}$.

Calculou-se a razão entre a quantidade de células em suspensão pela quantidade de células aderidas ao vidro dividindo-se as suas densidades ópticas.

O experimento foi feito com três repetições para a linhagem selvagem (J1a12) e ambos os mutantes gum.

\subsubsection{Avaliação do perfil protéico}

Os perfis protéicos dos mutantes e da linhagem selvagem J1a12 foram obtidos através de fracionamento por cromatografia líquida. 
As duas linhagens mutantes e a selvagem foram cultivadas em $250 \mathrm{ml}$ de meio PW por 7 dias e após esse período as células foram coletadas por centrifugação e ressuspendidas em $0,5 \mathrm{ml}$ do tampão $\mathrm{A}$ (Tris- $\mathrm{HCl} \mathrm{pH} 7,5$ ) contendo uma mistura de inibidores de proteases (1mM PMSF, 1mM EDTA, $1 \mu \mathrm{M}$ Leupeptin e $1 \mu \mathrm{M}$ Pepstatin). As células foram lisadas através de 10 ciclos de congelamento em nitrogênio líquido e descongelamento em banho Maria a $37^{\circ} \mathrm{C}$.

Cem microlitros dos sobrenadantes da lise foram aplicados em uma coluna de troca iônica (Mono Q) acoplada a um HPLC. Aplicou-se um gradiente salino de 0 a $100 \%$ do tampão $B$ (tampão $A+1 \mathrm{M} \mathrm{NaCl}$ ) à coluna com um fluxo constante de $1 \mathrm{ml} /$ minuto e os picos relativos às proteínas desprendidas da coluna foram registrados por um leitor de ultravioleta a $280 \mathrm{~nm}$.

3.2.10 Inoculação dos mutantes gum em plantas de citros e tabaco

Culturas de $30 \mathrm{ml}$ das linhagens mutantes e da linhagem selvagem foram crescidas por 10 dias em meio PW. Foi medida a densidade óptica (ABS ${ }_{590 \mathrm{~nm} \text { ) }}$ de cada uma das culturas e $20 \mu \mathrm{l}$ de diluições seriais foram semeadas para posterior contagem do numero de células no inóculo. As culturas foram então centrifugadas e, baseando-se nas suas densidades ópticas, estas foram ressuspendidas em tampão PBS de forma tentar igualar as suas concentrações de células.

\subsubsection{Inoculação em citros}

Foram utilizadas mudas de laranja (Citrus sinensis), variedade caipira com 6 meses de idade e aproximadamente $20 \mathrm{~cm}$ de altura. Os tratamentos desse experimento foram: dois clones de cada mutante, a linhagem selvagem e 
um controle negativo onde as plantas foram inoculadas apenas com o tampão PBS. Para cada tratamento foram usadas 6 plantas Para a inoculação, incisões em forma de "U" foram feitas nos dois lados do $8^{\circ}$ ou $9^{\circ}$ nó das plantas (Fig 7A). Uma gota de $50 \mu \mathrm{l}$ da suspensão de células em PBS foi colocada nas incisões (Fig 7B) e com uma agulha, foram feitos alguns furos na parte interna na incisão (Fig 7C). Deixou-se então que as gotas fossem absorvidas por alguns minutos e fechou-se as incisões com parafilme (Fig 7D).
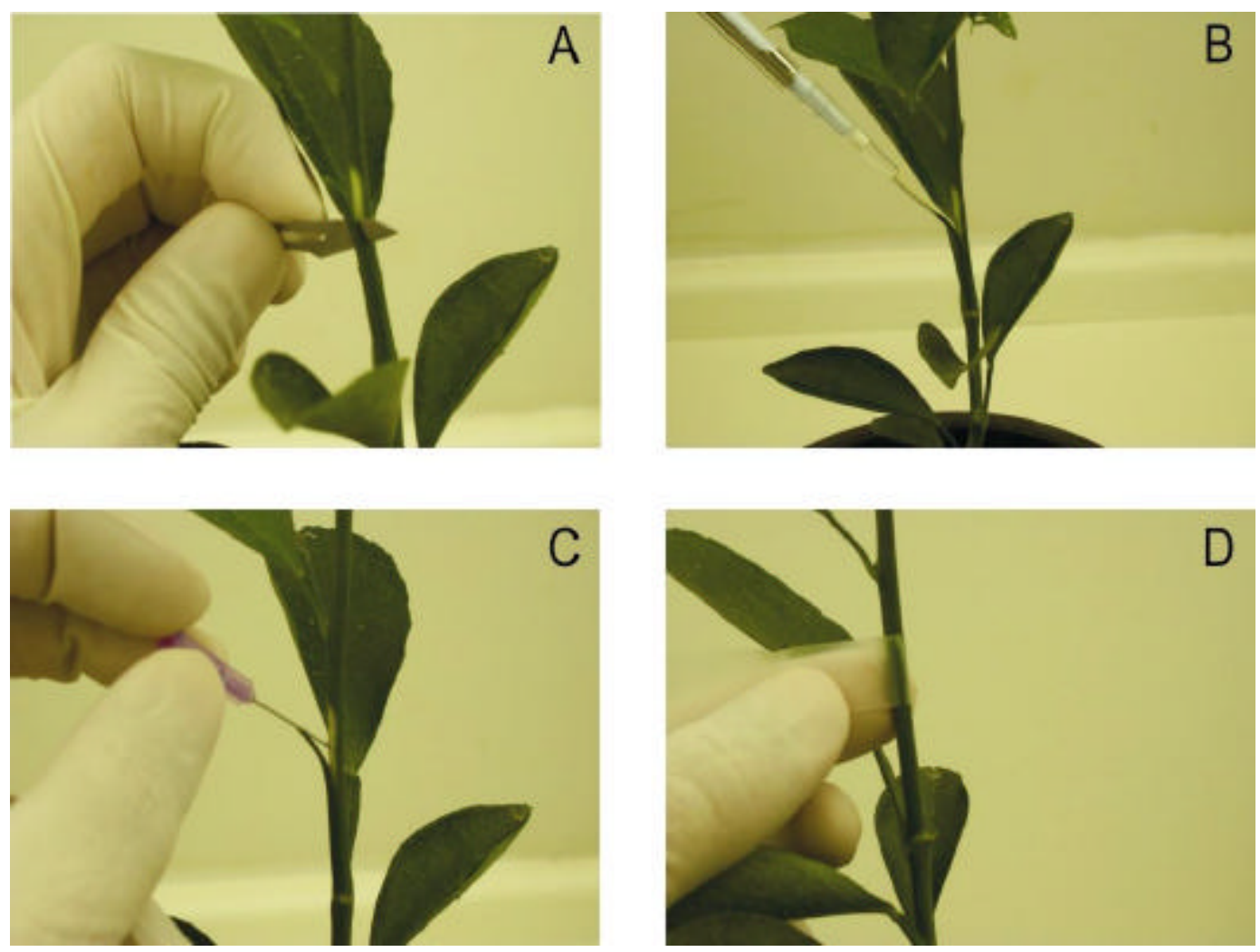

Figura 7 - Inoculação de Xylella fastidiosa em mudas de laranja.

\subsubsection{Inoculação em tabaco}

Foram usadas plantas de tabaco (Nicotiana clevelandii) com 55 dias de crescimento e aproximadamente $2 \mathrm{~cm}$ do caule. Os tratamentos usados nesse 
experimento foram: dois clones de cada mutante, a linhagem selvagem e um controle negativo onde as plantas foram inoculadas apenas com o tampão PBS. Para cada tratamento foram usadas 6 plantas. Dois dias antes da inoculação as plantas foram podadas de forma a deixar apenas duas folhas e deixadas sem água (não foram regadas) até a inoculação. Para a inoculação, uma gota de aproximadamente $30 \mu \mathrm{l}$ foi colocada no caule das plantas e com o auxílio de uma agulha fez-se de 5 a 8 furos na região do caule onde se encontrava a gota. Deixou-se absorver a gota por alguns minutos e adicionou-se outra gota de $30 \mu l$.

Todas as plantas (citros e tabaco) foram mantidas sob condições controladas de umidade (60\%), temperatura $\left(30^{\circ} \mathrm{C}\right.$ por $9 \mathrm{hs} ; 25^{\circ} \mathrm{C}$ por $1 \mathrm{~h} ; 20^{\circ}$ $\mathrm{C}$ por 12 hs e $25^{\circ} \mathrm{C}$ por 2 horas) e luminosidade (14 horas de luz / 10 horas de escuro).

Uma segunda inoculação foi feita em tabaco mantendo as plantas em casa de vegetação. 


\section{RESULTADOS E DISCUSSÃO}

\subsection{Construção do plasmídeo pDT8}

O plasmídeo pDT8 (Gaurivaud et al. 2002) foi utilizado como base para todas as contruções do presente trabalho. A descrição de sua construção é feita a seguir.

\subsubsection{Clonagem do gene Cloranfenicol Acetil Transferase (CAT)}

O plasmídeo pKPFCAT foi clivado com a enzima HindIII e o fragmento de $0,8 \mathrm{~Kb}$, contendo o gene CAT foi clonado no plasmídeo pBS digerido com a mesma enzima. A orientação correta do gene CAT foi verificada por uma análise de restrição, gerando o plasmídeo pC.

O gene CAT, clonado sem seu promotor e em fusão de transcrição com o gene alvo foi usado como repórter da integração do plasmídeo.

\subsubsection{Clonagem da origem de duplicação (OriC) de Xylella fastidiosa}

Para que o plasmídeo transformado se duplique dentro da célula de $X$. fastidiosa é necessário a presença de uma origem de duplicação nativa dessa bactéria, seja a origem de duplicação cromossômica (Monteiro et al. 2001b) ou 
uma origem de replicação plasmidial (Qin \& Hartung, 2001; Neto et al. 2002). Neste trabalho optou-se por utilizar a origem de duplicação cromossômica (OriC).

O plasmídeo pBK36dnaB foi clivado com a enzima $\mathrm{BamHI}$ e o fragmento de $366 \mathrm{pb}$ contendo a origem de duplicação cromossômica (OriC) de $X$. fastidiosa foi clonado no plasmídeo $\mathrm{pC}$ clivado com a mesma enzima. Uma análise desse fragmento contendo a OriC mostrou a existência do promotor do gene dnaN, que participa do processo de duplicação. Sendo assim, para evitar a interferência desse promotor sobre o gene CAT, o fragmento contendo a OriC foi clonado de forma que o seu promotor ficasse na orientação inversa ao gene CAT. A orientação correta dessa clonagem foi verificada por uma análise de restrição. O plasmídeo contendo a orientação desejada foi denominado pCO.

\subsubsection{Clonagem do gene aacA-aphD $\left(K a n^{\prime}\right)$}

O gene aacA-aphD, que confere resistência a canamicina, foi retirado do plasmídeo pUC4K por meio de clivagem com a enzima Pstl. As extremidades do fragemento de $1,2 \mathrm{~kb}$ contendo esse gene foram então tratadas com a enzima "Klenow" de forma a deixa-las com extremidades abruptas (do inglês "Blunt"). Esse fragmento foi então clonado no plasmídeo pCO clivado com a enzima Smal.

Assim como no caso da clonagem do fragmento contendo a OriC, o gene aacA-aphD foi clonado na orientação reversa ao gene CAT. Essa orientação foi selecionada por análise de restrição. Ao plasmídeo gerado deu-se o nome de pCOK. 


\subsubsection{Clonagem da cauda de tmRNA de Xylella fastidiosa}

No genoma de $X$. fastidiosa também foi identificado um tmRNA e, baseado no trabalho de Molnos et al. (2000), esse sistema também foi usado para garantir a completa inativação dos genes alvo.

O fragmento de DNA obtido a partir da dimerização dos oligonucleotídeos Tm1 e Tm2, foi clivado com as enzimas Sphl e Pstl e clonado no plasmídeo pCOK clivado com as mesmas enzimas. A verificação da presença da cauda tmRNA foi feita por meio de clivagem com as mesmas enzimas da clonagem e visualização em gel de poliacrilamida $20 \%$ (resultados não mostrados). Gerou-se assim o plasmídeo pDT8 (Plasmídeo para Disrupção contendo a cauda de tmRNA, clone 8).

\subsection{Construção dos vetores para mutagênese por inserção-deleção (IDM) dos genes gumB, gumD e gumF}

Usando os oligonucleotídeos GBF, GBR, GDF, GDR, GFF e GFR descritos (ver item 3.1.5), e DNA genômico extraído da linhagem J1a12 de $X$. fastidiosa, foram amplificados por PCR, os genes gumB, gumD e gumF (Figura 8). 


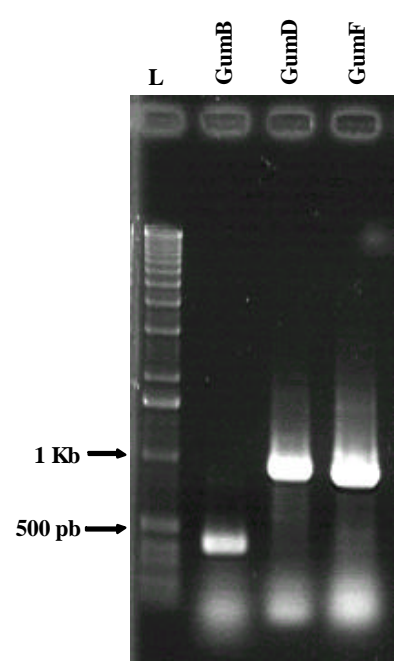

Figura 8 - Amplificação dos genes gumB, gumD e gumF.

Nota: As bandas dos genes possuem respectivamente 421, 921 e 859 pares de bases. $L=$ marcador de peso molecular "1Kb DNA Ladder".

O sítio Pstl foi inserido nos primers GBR, GDR e GFR de forma a deixar esses genes na mesma fase de leitura da cauda de tmRNA. O gene gumF foi clonado no plasmídeo pGEM-T para facilitar a sua manipulação. Os produtos de amplificação dos genes gumB e gumD foram clivados com as enzimas Pstle Accl e clonados no plasmídeo pDT8 clivado com as mesmas enzimas. Geraram-se então os plasmídeos para a disrupção dos genes gumB e gumD denominados respectivamente de pGB8 e pGD8 (Figura 9 A e B).

O gene gumF foi retirado do plasmídeo pGEM-T com a enzima Pstl (um sítio presente no amplificado e outro no plasmídeo) e clonado no plasmídeo pDT8 clivado com a mesma enzima. A orientação correta em relação à cauda de tmRNA foi verificada por análise de restrição. Gerou-se então o plasmídeo pGF8 para disrupção do gene gumF (Figura $9 \mathrm{C}$ ). 


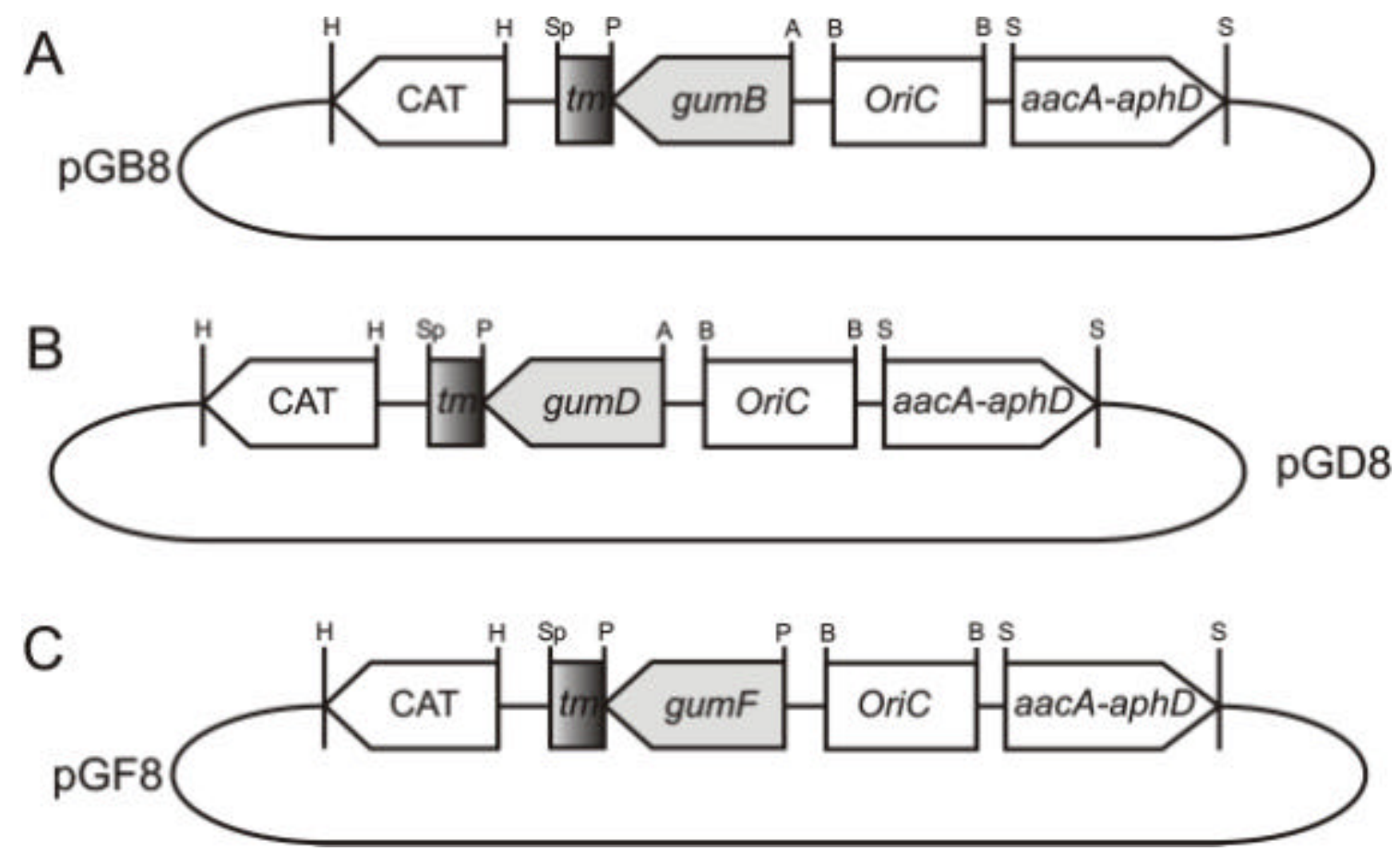

Figura 9 - Esquema dos plasmídeos usados para disrupção dos genes gum por IDM.

$\mathrm{H}=$ HindlII, $\mathrm{Sp}=S p h l, \mathrm{P}=P s t l, \mathrm{~B}=\mathrm{BamH} I, \mathrm{~S}=\mathrm{Smal}$

\subsection{Construção dos vetores para inativação dos genes gumD e gumF por troca alélica (AE)}

Os genes marcadores escolhidos para a disrupção foram o gene CAT, que codifica a enzima cloranfenicol acetil transferase e confere resistência a cloranfenicol; e o gene AMP que codifica a enzima $\beta$-lactamase e confere resistência a ampicilina. Os oligonucleotídeos CATF, CATR, AMPF e AMPR foram desenhados, todos contendo o sítio para a enzima $\mathrm{Ndel}$, de forma a amplificar os genes marcadores sem o promotor e sem o terminador de transcrição. A ausência do terminador garante que a inativação do gene alvo 
não acarrete na parada da transcrição dos genes localizados ajusante no operon. Usando-se o plasmídeo pC como molde foram amplificados os genes CAT e AMP (Figura 10).

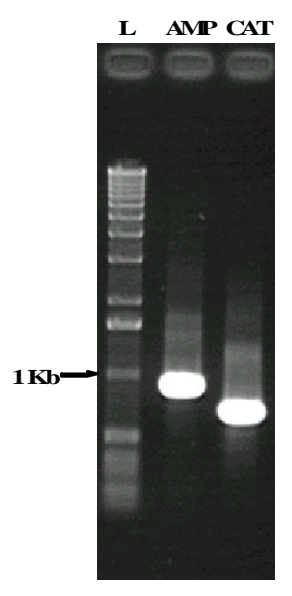

Figura 10 - Amplificação dos genes AMP e CAT.

Nota: As bandas correspondem a 880 e 660 pares de bases respectivamente, $\mathrm{L}=$ marcador de peso molecular "1kb DNA Ladder".

Os genes gumD e gumF foram amplificados usando-se os oligonucleotídeos GDF, GDR, GFF, GFR e clonados em pGEM-T formando os plasmídeos pGD e pGF. Os genes gumD e gumF possuem um sítio interno para a enzima $\mathrm{Ndel}$ que divide os amplicons em duas partes com tamanho suficiente para o evento de recombinação. A clivagem com $\mathrm{Ndel}$ do amplicon gumD gera fragmentos de 253 e 668pb e a clivagem de gumF gera fragmentos de 270 e $589 p b$.

Não foi feita a construção para a troca alélica do gene gumB devido a ausência de sítios internos para a clonagem do gene marcador e ao fato do amplicon desse gene ser muito pequeno (421 pb), o que diminuiria muito a probabilidade da ocorrência de duas permutas. 
Para a clonagem dos genes CAT ou AMP no sítio Nde I dos genes gumD e gumF fez-se necessária a retirada do sítio Nde I presente no plasmídeo pGEM-T. Para tal, clivou-se o plasmídeo com as enzimas Sall e Sacl que flanqueiam o sítio Ndel, preencheu-se as extremidades com a enzima "Klenow" e fez-se a religação do plasmídeo.

Os genes CAT e AMP foram subclonados no sítio Ndel dos genes gumD e gumF e sua orientação foi determinada por PCR. Foram selecionados os clones onde o gene marcador e o gene gum estavam na mesma orientação. Geraram-se então os plasmídeos pGDA, pGDC, pGFA e PGFC. O seqüênciamento desses plasmídeos confirmou as amplificações e a orientação desejada das construções.

Os cassetes contendo os genes gum e os genes marcadores foram retirados dos plasmídeos pGDA, pGDC, pGFA e PGFC por clivagem com a enzima Pstl e ligados no plasmídeo pCOK clivado com a mesma enzima. Gerou-se então os plasmídeos para troca alélica pDA (pCOK + cassete gumDAMP), pDC (pCOK + cassete gumD-CAT), pFA (pCOK + cassete gumF-AMP) e pFC (pCOK + cassete gumF-CAT). Os esquemas desses plasmídeos são mostrados na Figura 11. 

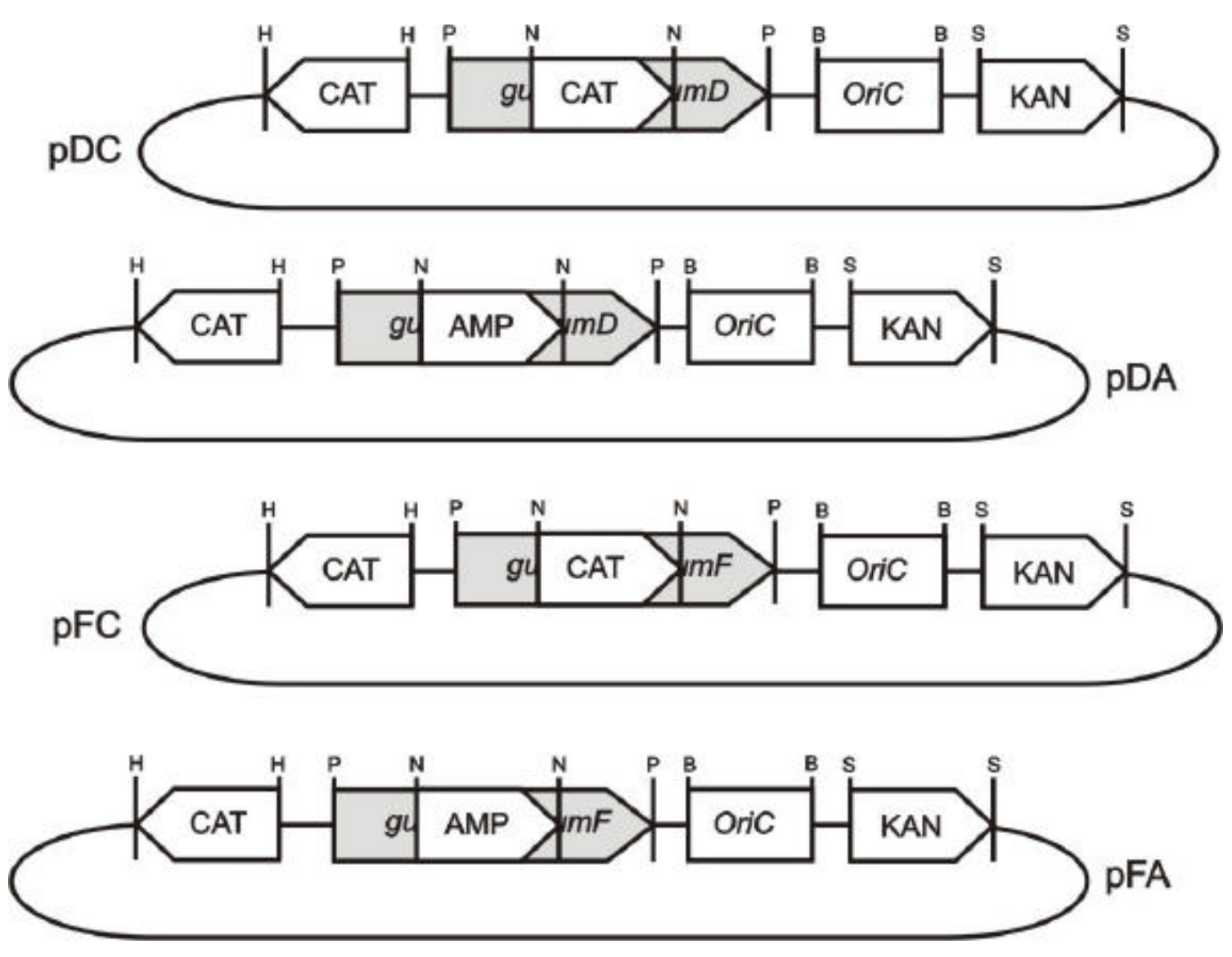

Figura 11 - Esquema dos plasmídeos usados para disrupção dos genes gum por AE.

$\mathrm{H}=$ HindIII, $\mathrm{P}=P$ st, $\mathrm{N}=$ Ndel, $\mathrm{B}=\mathrm{BamH} \mathrm{I}, \mathrm{S}=\mathrm{Smal}$

\subsection{Obtenção dos mutantes por troca alélica (AE)}

Para a obtenção dos mutantes de $X$. fastidiosa por troca alélica envolvendo duas permutas, a linhagem selvagem J1a12 foi transformada com os plasmídeos pDA, pDC, pFA e pFC seguindo o protocolo descrito no item 3.2.3. Colônias transformantes apareceram entre 20 e 30 dias. 
Os transformantes contendo os plasmídeos pDA e pFA foram cultivados em meio contendo ampicilina $(20 \mu \mathrm{g} / \mathrm{ml})$. Devido ao fato da ampicilina ser pouco estável e ser degradada antes do tempo necessário para um repique, notou-se que após alguns repiques os transformantes perdiam seus plasmídeos devido a ausência da pressão do antibiótico. Isso acarretava na morte das células quando essas culturas eram transferidas. Resolveu-se então abandonar a estratégia usando o gene AMP como marcador de integração.

No caso dos transformantes contendo o gene CAT como marcador ( $\mathrm{pDC}$ e $\mathrm{pFC})$, as culturas foram cultivadas tanto em meio com ampicilina $(20 \mu \mathrm{g} / \mathrm{ml})$ ou com canamicina $(10 \mu \mathrm{g} / \mathrm{ml})$. Para o meio contendo ampicilina, também emfrentou-se o problema da perda de plasmídeos e morte das células após os repiques. As culturas com canamicina se mantiveram estáveis e, a cada repique, parte dessas culturas eram semeadas em meio contendo $5 \mu \mathrm{g} / \mathrm{ml}$ de cloranfenicol a fim de selecionar os mutantes integrados. Após várias tentativas não foram obtidas colônias resistentes a cloranfenicol. Verificou-se assim, a necessidade de um sistema de seleção mais eficiente devido à raridade do evento de dupla recombinação homóloga e abandonou-se também a estratégia usando o gene CAT como marcador de integração.

Outra falha encontrada na estratégia de troca alélica foi o fato de nada ser conhecido sobre a expressão dos genes alvo. Se esses genes não forem expressos, ou tiverem um nível de expressão baixo em meio de cultura, os genes marcadores não cumpririam seu papel por estarem sob o controle do promotor endógeno do gene alvo.

Para a melhor compreensão do papel individual dos genes gum, a obtenção de mutantes por troca alélica torna-se imperativa, sendo necessário o uso de um gene marcador contendo o seu promotor e um forte sistema de seleção para o evento de dupla permuta. Esta estratégia envolve a construção de um plasmídeo contendo a origem de duplicação de $X$. fastidiosa, o gene aac $A$-aph $D$, com seu promotor interrompendo o gene alvo e o gene sacB que codifica a enzima levansucrase, uma frutosil transferase como contra-seleção. 
Em bactérias Gram-negativas, a expressão do gene sacB em presença de sacarose é fatal devido ao acúmulo de polímeros de frutose no periplasto. Esse sistema já foi usado com sucesso em E. coli (Donnenberg \& Kaper, 1991).

\subsection{Obtenção dos mutantes por inserção-deleção (IDM)}

Assim como no caso dos transformantes por troca alélica, as primeiras colônias da linhagem J1a12 transformada com os plasmídeos pGB8, pGD8 e pGF8 apareceram entre 20 e 30 dias após a transformação.

Repiques sucessivos de 5 culturas de cada transformante foram feitas em meio PW contendo $10 \mu \mathrm{g} / \mathrm{ml}$ de canamicina. A análise por Southern blot dessas culturas, usando o plasmídeo pBS como sonda, detectou a integração dos plasmídeos na sexta passagem de algumas culturas. Um outro Southern blot das mesmas culturas, usando como sonda os genes alvo, mostrou que a integração havia ocorrido no gene alvo em duas culturas para os transformantes contendo os plasmídeos para mutação dos genes gumB e gumF, e que em duas culturas contendo o plasmídeo para a mutação do gene gumD, a integração ocorreu na OriC.

$\mathrm{Na}$ nona passagem observou-se que em todas as culturas contendo o plasmídeo para a mutação do gene gumD a integração ocorreu na OriC. Sendo assim, não se conseguiu a obtenção de mutantes para o gene gumD.

Duas razões podem explicar a não obtenção dos mutantes gumD: uma hipótese probabilística e uma hipótese de letalidade da mutação. A hipótese probabilística leva em conta que, como o plasmídeo de disrupção pode se integrar tanto no gene alvo como na origem de replicação, probabilisticamente é possível que em cinco culturas todas se integrem em uma das duas opções. A hipótese da letalidade da mutação supõe que a mutação no gene gumD leva a mortalidade das células seja por acúmulo de intermediários tóxicos ou por efeitos pleiotrópicos sobre outras funções celulares. Gaurivaud et al. (2002), trabalhando com o mesmo plasmídeo, observaram que quando o fragmento do 
gene clonado no plasmídeo de disrupção era maior do que a origem de replicação, havia uma preferência de integração no gene alvo. Como o fragmento do gene gumD usado no plasmídeo de disrupção pGD8 é de 921pb, quase três vezes o tamanho da origem de replicação (366 pb), a probabilidade da integração ocorrer apenas na origem de replicação, sem a interferência de algum outro fator, se torna muito pequena. Sendo assim, a segunda hipótese, que supõe que a mutação no gene gumD leva a mortalidade das células, tornase a mais provável. Apesar dessas evidências, não é possível afirmar que essa hipótese esteja correta.

\subsection{Obtenção de culturas puras dos mutantes gumB e gumF e determinação da configuração genômica das integrações}

Culturas puras dos mutantes gumB e gumF foram obtidas por meio de tripla clonagem das culturas onde se detectou a integração dos plasmídeos nos genes alvo. A análise por Southern blot confirmou a presença apenas de integraçoes nos genes alvo nas culturas puras.

Dois clones de cada mutante foram selecionados para os experimentos subseqüentes.

Para montar um mapa de restrição de toda a região cromossômica compreendendo os genes gumB e gum $F$, fez-se uma análise conjunta por Southern blot dos mutantes utilizando como sonda os genes gumB, gumF, CAT e a OriC. Para essa análise, o DNA genômico dos mutantes e da linhagem selvagem foram clivados com as enzimas Sphle Smal.

Essa análise reconfirmou a integração dos plasmídeos nos genes alvo e para o gene gumB, a integração ocorreu de acordo com a orientação esperada. Todavia, para o gene gumF, a análise conjunta revelou que a integração do plasmídeo pGF8 ocorreu no sentido oposto ao esperado. Os Southern blots e os mapas de restrição gerados a partir deles são mostrados nas Figuras 12 e 13 respectivamente. 
Mesmo tendo ocorrido a integração do plasmídeo pGF8 na orientação invertida, o gene gumF também foi inativado. Está configuraçao, no entanto, impede a utilização do gene CAT como um repórter de integração, já que este também se encontra na posição invertida em relação ao promotor endógeno do gene alvo. Outra conseqüência dessa integração invertida é a inutilização da cauda de tmRNA que também ficou na posição invertida.

A explicação para que o plasmídeo tenha se integrado na posição invertida está no fato de ter sido usado na transformação, por acidente, um clone contendo o gene gumF clonado na posição invertida, ao invés de um clone com a orientação desejada. 

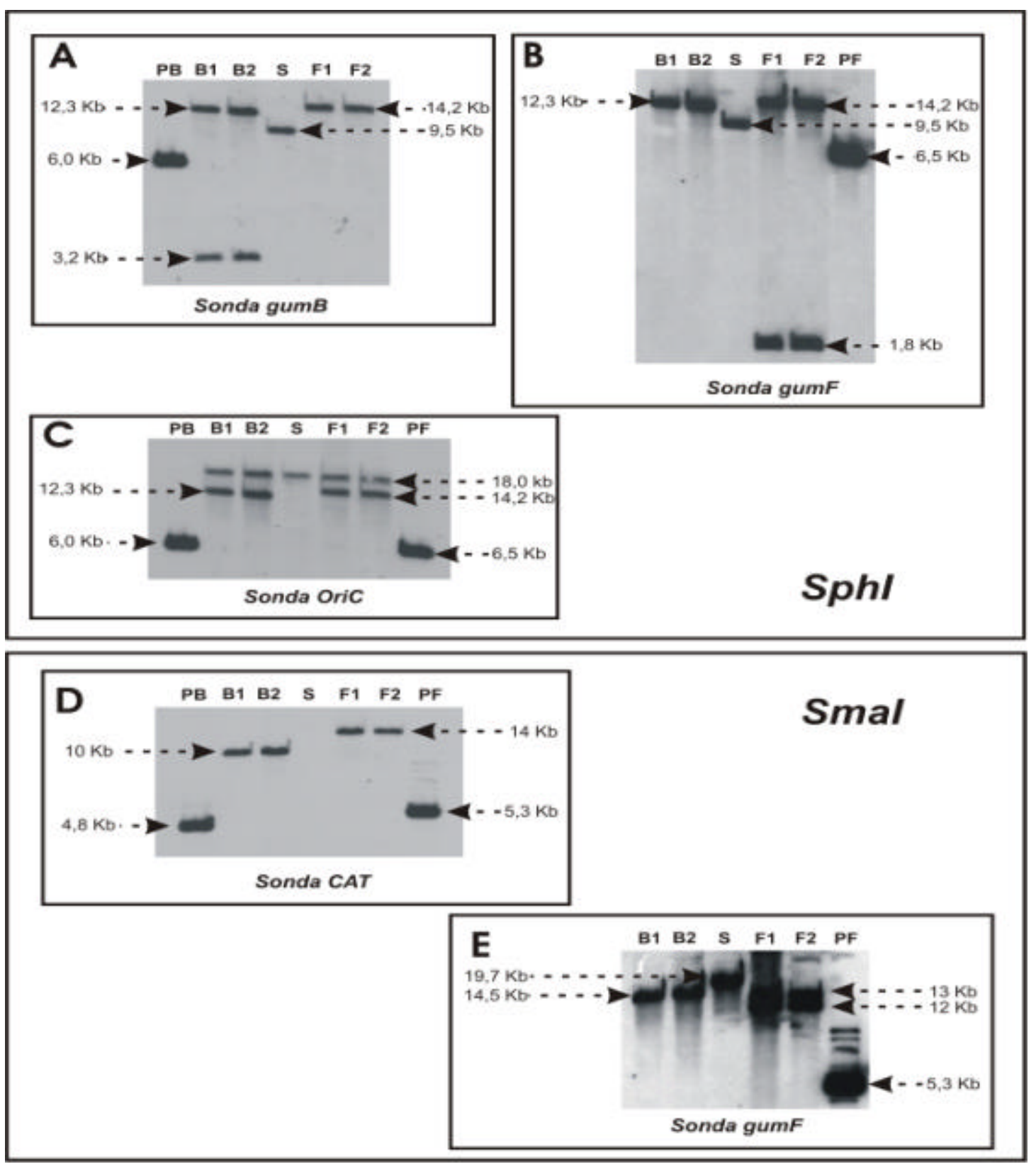

Figura 12 - Análise comparativa por Southern blot dos mutantes gumF e gumB.

$\mathrm{PB}=$ plasmídeo pGB8; $\mathrm{PF}=$ plasmídeo pGF8; $\mathrm{B} 1=$ Mutante gum $B$ clone $1 ; \mathrm{B} 2=$ Mutante gumB clone 2; F1 = Mutante gumF clone 1; F2=Mutante gumF clone 2.

Nota: Em A, B e C o DNA genômico foi clivado com a enzima Sphle em D e E foi usada a enzima Smal. 
A

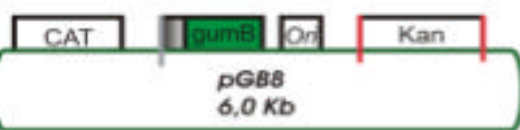

B

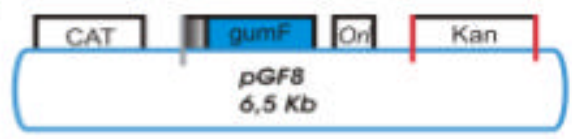

C

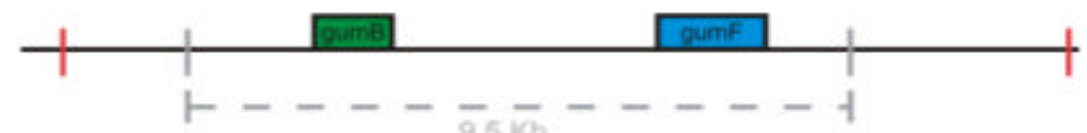

$1-----\frac{9,5}{19,7} \mathrm{~kb}---1$

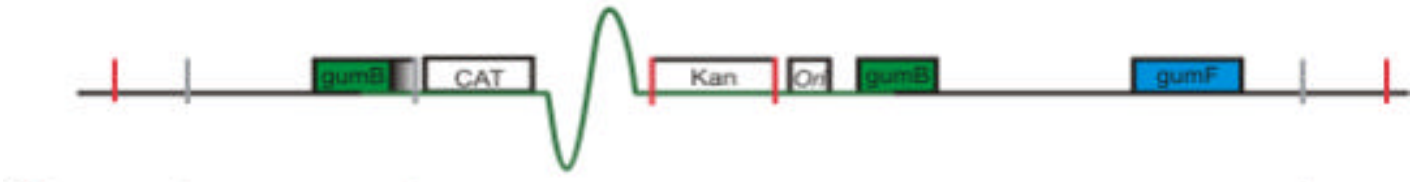

D

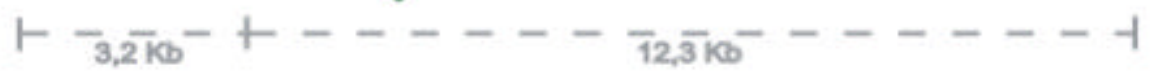

$\vdash---\overline{10}_{10} \overline{\mathrm{Kb}}---1 \overline{1}_{1,2} \overline{\mathrm{Kb}}+---\overline{14,5} \overline{\mathrm{Kb}}---+$

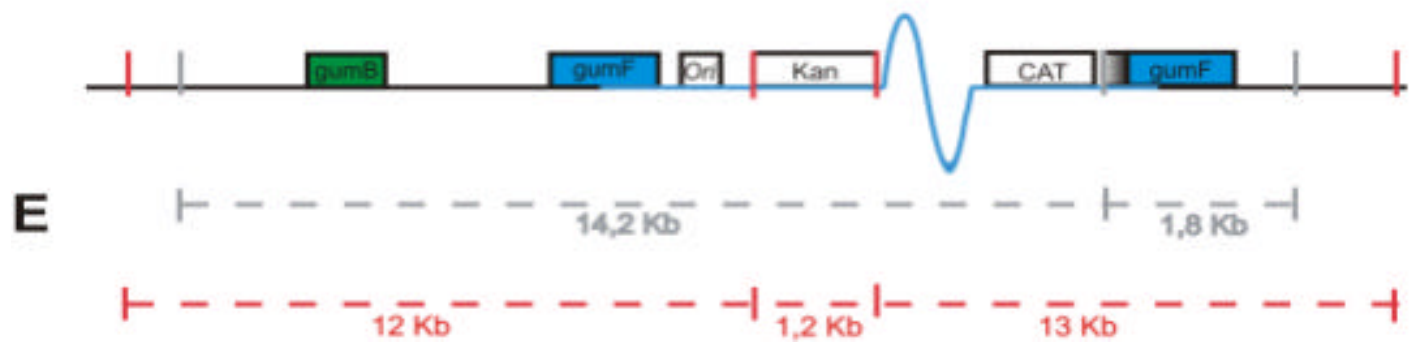

Figura 13 - Mapa mostrando a organização genômica da região que compreende os genes gumB e gumF.

Nota: Em vermelho e cinza, a posição dos sítios e o tamanho dos fragmentos genômicos para as enzimas Smale Sphl, respectivamente. Em A e B, plasmídeos pGB8 e pGF8 respectivamente. Em C, organização genômica da linhagem selvagem; em $D$, organização da integração do plasmídeo pGB8 no gene gumB; e em E, a organização da integração invertida do plasmídeo pGF8 no gene gumF. A caixa com coloração gradiente representa a cauda tmRNA. 


\subsection{Análise da expressão do gene repórter CAT nos mutantes}

Devido ao fato do gene CAT estar sob a ação do promotor do operon gum nos mutantes gumB, a avaliação da resistência dos mutantes ao cloranfenicol sob diferentes condições pode trazer informações relativas à expressão desse operon.

A Figura 14 mostra graficamente os resultados obtidos da avaliação da resistência a cloranfenicol para o mutante para o gene gumB em meio PW normal e suplementado com $1 \%$ de glicose em um experimento feito com três repetições.

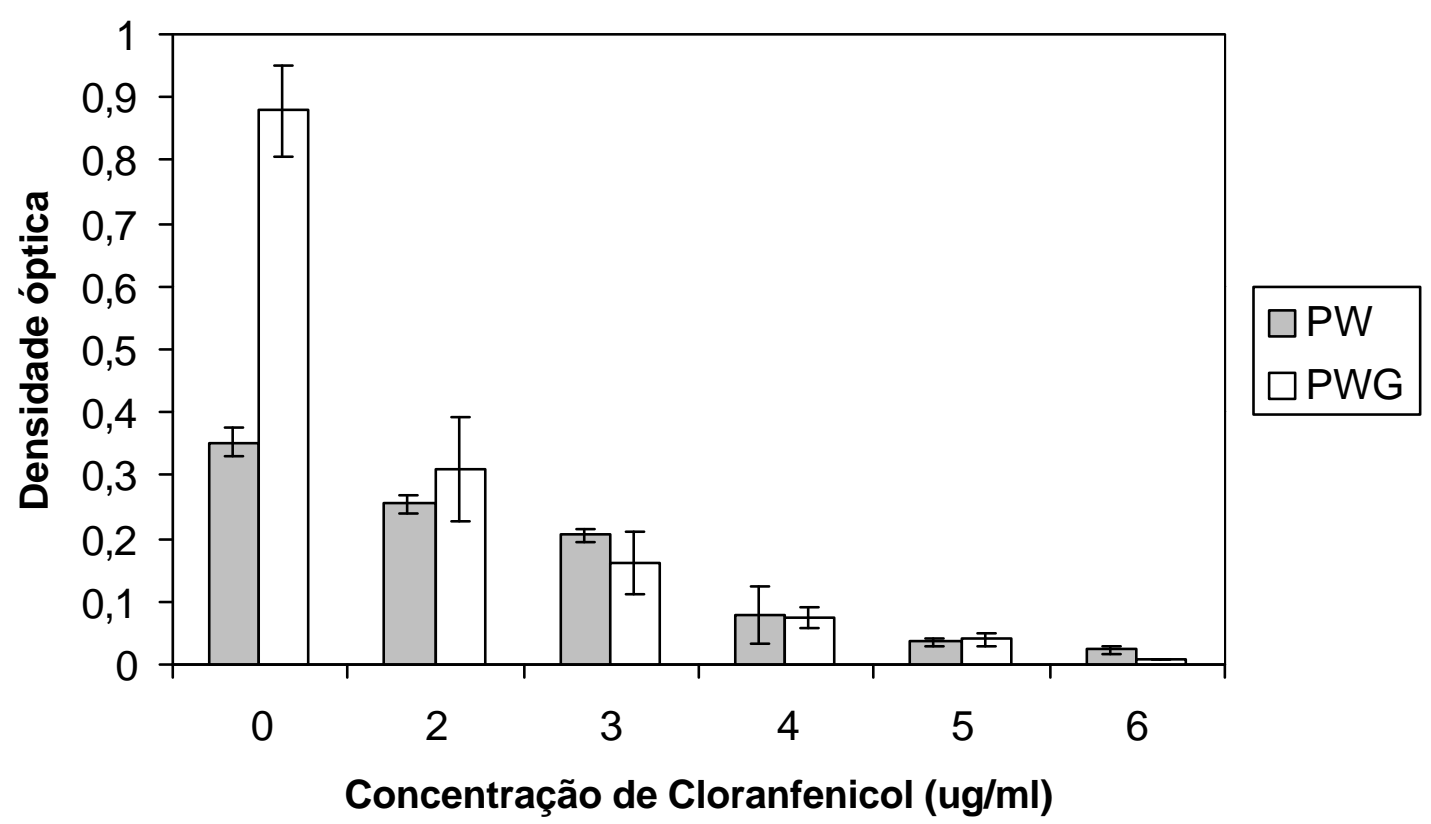

Figura 14 - Avaliação da resistência do mutante gumB a cloranfenicol em meio PW normal e suplementado com $1 \%$ de glicose.

Nota: As linhas verticais nas colunas do gráfico representam os desvios padrão. 
A linhagem selvagem J1a12 apresentou grande susceptibilidade a cloranfenicol, tendo o seu crescimento totalmente inibido logo na concentração de $2 \mu \mathrm{g} / \mathrm{ml}$ (resultados não apresentados).

Em $X$. campestris, a glicose possui grande influência na expressão do operon gum, mostrando uma clara indução da sua expressão nas primeiras 12 horas de cultivo (Vojnov et al. 2001). Como mostrado na Figura 14, em $X$. fastidiosa a glicose não induz a expressão do operon gum.

Uma boa razão para esse comportamento diferente do operon gum de $X$. campestris e $X$. fastidiosa está no próprio estilo de vida dessas bactérias. A $X$. campestris é um patógeno invasivo, que para atacar o hospedeiro invade os seus tecidos rompendo as suas células em busca de alimento. Em contraposição a esse ambiente rico em glicose em que vive a $X$. campestris, a $X$. fastidiosa vive em um ambiente extremamente pobre em carboidratos. Como ambos os organismos necessitam, ao menos teoricamente no caso de $X$. fastidiosa, da sua goma para a sua sobrevivência no hospedeiro, é de se esperar que a produção desses exopolissacarídeos esteja associada ao ambiente em que vivem.

Apesar do mutante gumF ter o seu plasmídeo integrado na direção oposta a esperada, deixando o gene CAT também na direção oposta, também foi observada resistência a cloranfenicol no mutante gumF. Essa resistência demonstrada pelo mutante gumF se mostrou superior aquela mostrada pelo mutante gumB. Em um experimento testando-se várias concentrações de cloranfenicol, observou-se que a inibição total do crescimento dos mutantes gumF só ocorreu com $8 \mu \mathrm{g} / \mathrm{ml}$ de cloranfenicol em meio PW e com $10 \mu \mathrm{g} / \mathrm{ml}$ em meio PWG (1\%). A figura 15 mostra graficamente esses resultados. 


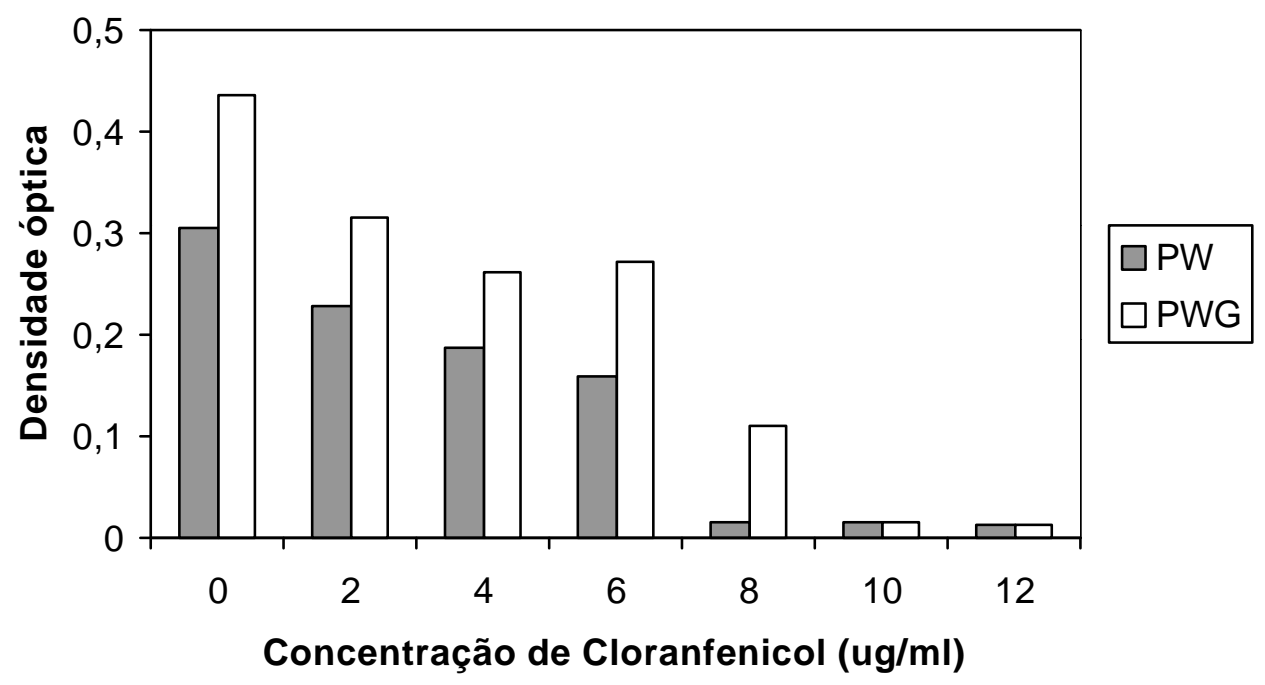

Figura 15 - Avaliação da resistência do mutante gumF a cloranfenicol em meio PW normal e suplementado com $1 \%$ de glicose.

Para confimar a presença do gene CAT no sentido mostrado pelo Southern blot e para descartar a hipótese de um rearranjo cromossômico envolvendo o plasmídeo pGF8, fez-se um PCR, utilizando-se os oligonucleotídeos CATR com GFF e GFR, com DNA do mutante gumF como molde e; com os oligonucleotídeos CATR com GBF e GBR, com DNA do mutante gumB como molde servindo como um controle. O PCR (Figura 16) revelou que o gene CAT encontra-se realmente na orientação inversa em relação ao sentido da transcrição do operon no mutante gumF. 


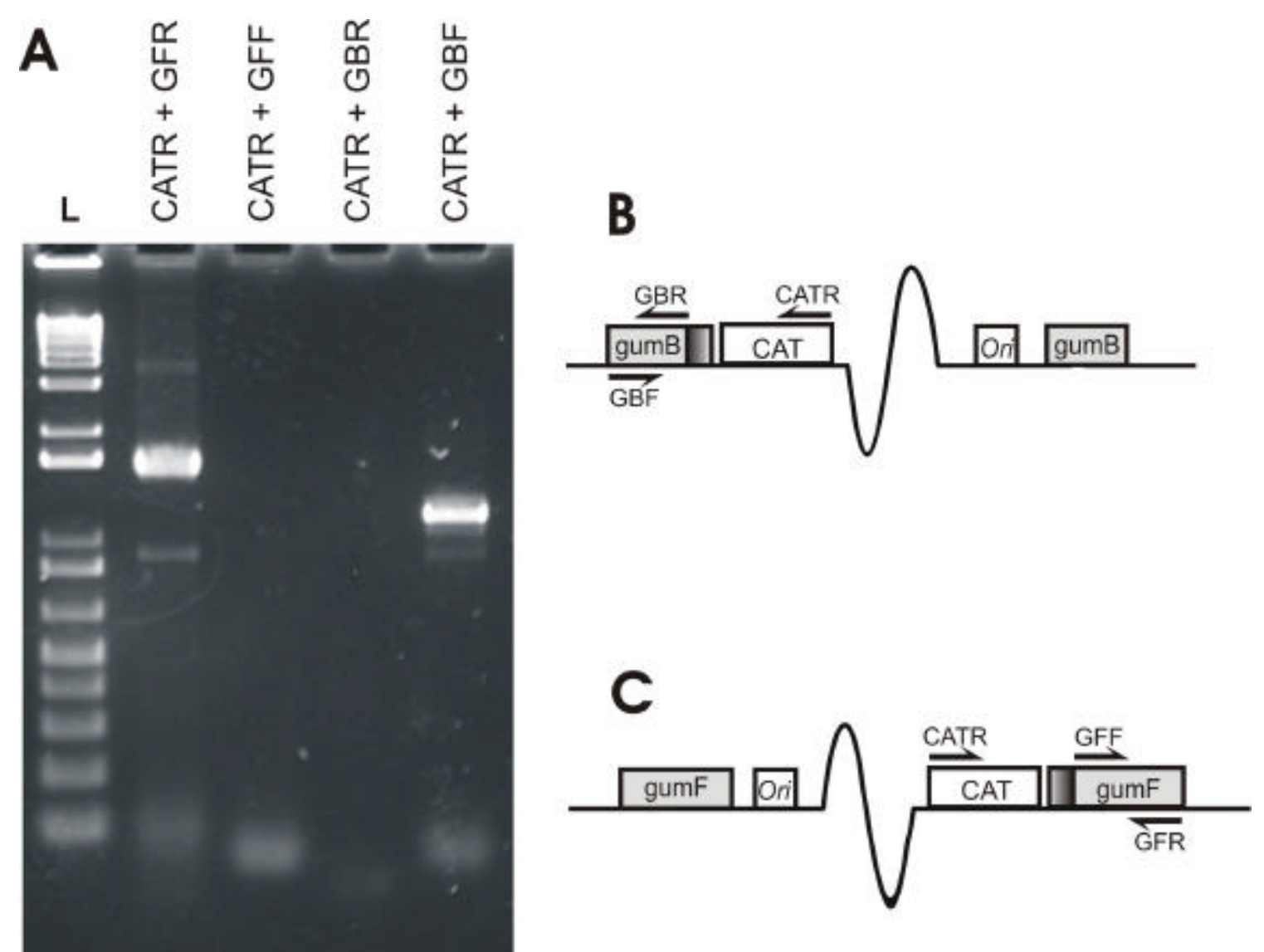

Figura 16 - Determinação por PCR da orientação do gene CAT em relação aos gene gumF.

$\mathrm{L}=$ Ladder "1Kb DNA ladder plus"

Nota: Em A, gel de agarose 1,4\% mostrando o resultado do PCR, a banda de 1550pb em CATR + GFR confirma a orientação esperada. As outras canaletas representam os controles. Em B e C, esquema mostrando a orientação e localização dos oligonucleotídeos no cromossomo dos mutantes gumB e gumF.

Esse resultado indica a existência de um promotor na fita complementar do operon gum, que está dirigindo a expressão do gene CAT no mutante gumF.

Para tentar localizar esse promotor desconhecido foi feita uma procura por fases abertas de leitura (ORFs) na fita antisenso do operon gum. Esta busca 
não revelou nenhum peptídeo com homologias significativas. Estudos mais específicos devem ser feitos para localizar e caracterizar o promotor e essa região transcrita desconhecida do genoma de $X$. fastidiosa.

\subsection{Análise morfológica dos mutantes gumB e gumF}

A análise da morfologia tanto das células, quanto das colônias mutantes em meio PW não evidenciou qualquer mudança significativa em relação à linhagem selvagem J1a12. As células não alteraram seu tamanho, forma ou padrão de agregação na análise por microscopia óptica.

A forma, o brilho e o tamanho das colônias se mantiveram inalterados quando observados em estereomicroscópio (resultados não mostrados).

As colônias de $X$. campestris mutantes para os genes gum apresentam morfologias diferentes das suas linhagens selvagens, sendo suas colônias não mucóides, menores e mais escuras (Chou \& al. 1997). No entanto, em sua revisão sobre o envolvimento dos polissacarídeos bacterianos na patogênese de bactérias, Denny (1995) cita que a morfologia das colônias nem sempre é afetada pela não produção de polissacarídeos. A ausência de alterações na morfologia das colônias e células dos mutantes gum de $X$. fastidiosa produzidos, mostra mais uma importante diferença entre a goma fastidiana e a goma xantana.

Outro ponto importante a ser discutido é o fato das células em suspensão, continuarem apresentando o mesmo padrão de agregação nos mutantes e nos selvagens. Assumia-se que a goma fastidiana era a responsável pela formação dos grumos de $X$. fastidiosa em meio de cultura (Leite et al. 2002). O resultado apresentado aqui indica que a agregação celular está relacionada a outros fatores como fímbrias, adesinas ou interações entre agrupamentos de cargas negativas presentes nas membranas. 


\subsection{Avaliação do efeito da mutação nos genes gumB e gumF na adesão de Xylella fastidiosa}

A capacidade de adesão de $X$. fastidiosa foi testada em um ensaio feito em tubos de vidro.O experimento foi feito comparando-se os mutantes para os genes gumB e gumF e a linhagem selvagem J1a12, em uma passagem equivalente a dos mutantes, cultivados em meio PW suplementado ou não com glicose.

Como mostrado graficamente na Figura 17, a mutação nos genes gum não afetou a relação entre a densidade óptica das células aderidas (DO cristal violeta) e a densidade óptica das células em suspensão (DO culturas). Esse resultado indica que a goma fastidiana não possui papel preponderante no processo de adesão das células ao substrato.

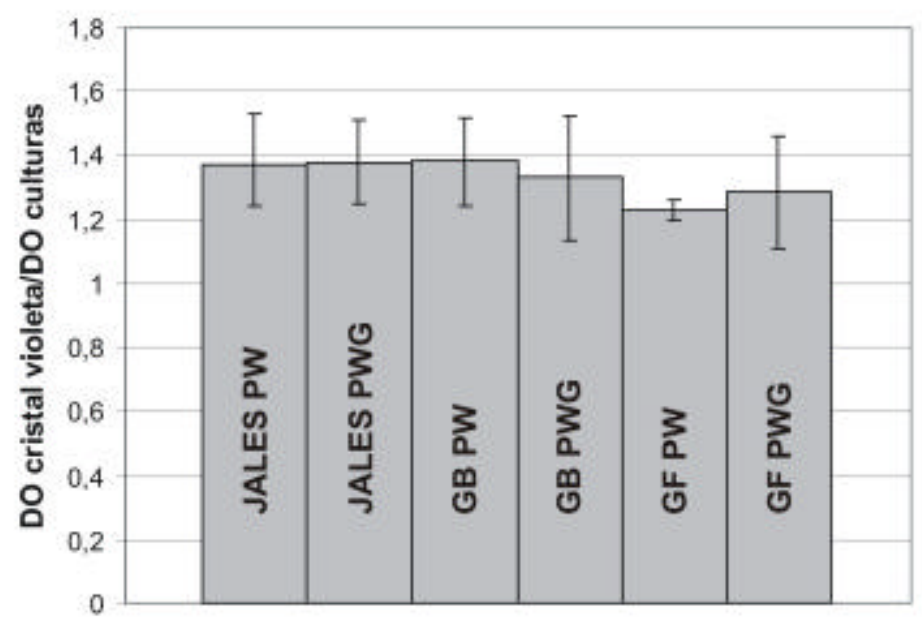

Figura 17 - Gráfico da relação entre a densidade óptica das células aderidas (DO cristal violeta) e a densidade óptica das células em suspensão (DO culturas) no experimento de adesão em vidro.

Nota: As linhas verticais nas colunas do gráfico representam os desvios padrão. 
Mesmo com um maior número de células no meio, devido a adição de glicose, a relação DO cristal violeta/DO culturas não se alterou, indicando também que a adição de glicose no meio não interfere no processo de adesão de $X$. fastidiosa em vidro.

Considerando que não foi detectada mudança no padrão de agregação dos mutantes gum de $X$. fastidiosa, esse resultado vem apoiar a hipótese de que a provável goma fastidiana não está envolvida diretamente na agregação de $X$. fastidiosa ao seu substrato (Leite et al. 2002). Watnick \& Kolter (2000) e Davey \& O'Toole (2000) também citam em suas revisões sobre biofilmes bacterianos que os exopolissacarídeos não estão envolvidos na agregação das bactérias nos biofilmes e sim, na formação de uma estrutura de proteção e captação de nutrientes.

Sendo assim, assume-se que a goma fastidiana está envolvida em funções dentro do biofilme de $X$. fastidiosa diferentes da adesão ou agregação das células.

\subsection{Avaliação do perfil protéico dos mutantes gum}

\footnotetext{
A comparação dos perfis de proteínas solúveis dos mutantes $g u m B$ e gumF de $X$. fastidiosa foi feita com o intuito de avaliar a influência da inativação desses genes na expressão global de proteínas dessa bactéria.

Os perfis cromatográficos obtidos para os dois mutantes gum e para a linhagem selvagem estão mostrados na figura a seguir (Figura 18)
} 


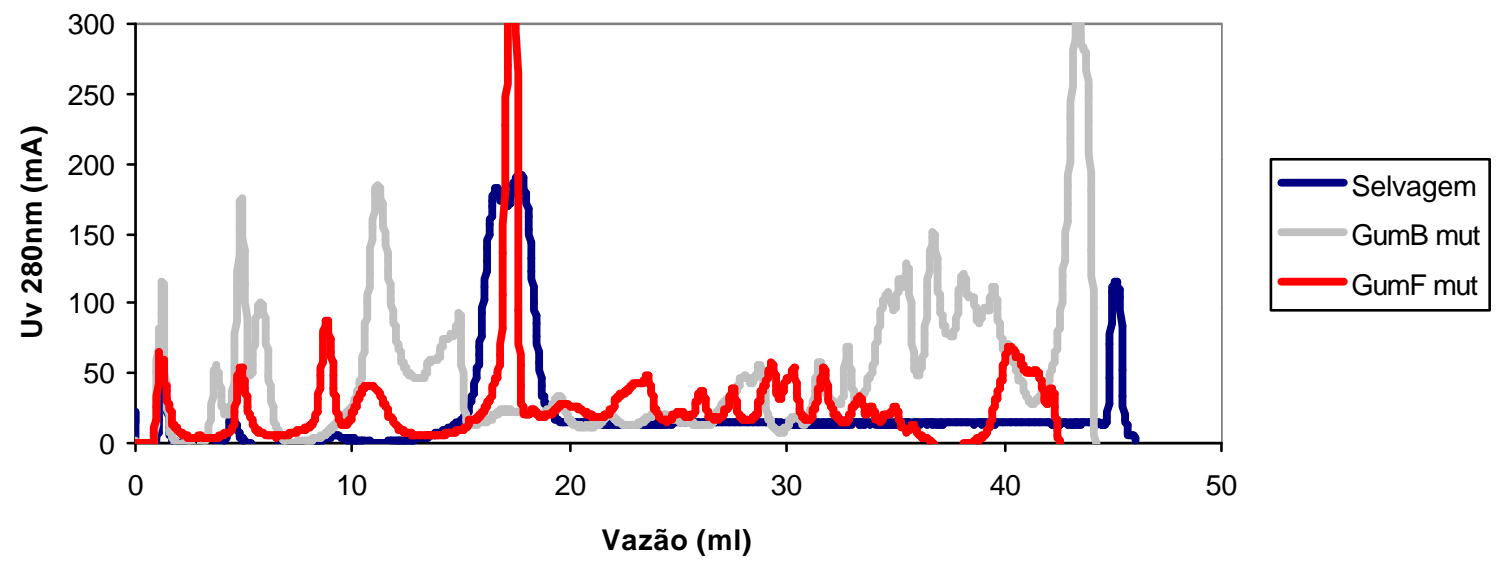

Figura 18 - Cromatograma mostrando o perfil de proteínas solúveis dos mutantes gumB e gumF e da linhagem selvagem J1a12.

Os cromatogramas mostram que existem grandes diferenças nos perfis protéicos entre os mutantes e a linhagem selvagem. O efeito pleiotrópico de mutações em genes envolvidos na síntese de exopolissacarídeos já foi observado em Rhizobium leguminosarum (Guerreiro et al. 2000). Nesse trabalho, usando-se géis de eletroforese em duas dimensões (2D-PAGE), observou-se que um mutante para o gene $p s s A$, um dos responsáveis pela produção de um exopolissacarídeo, mostrou a indução de mais de vinte outras proteínas, a maioria de função desconhecida.

Esses resultados indicam que os genes do operon gum de $X$. fastidiosa e a goma fastidiana podem estar envolvidos em outros processos celulares de forma direta ou indireta.

\subsection{Inoculações dos mutantes gum em plantas de citros e tabaco}

Para avaliar a influência da inativação dos genes gumB e gumF na patogênese de $X$. fastidiosa, os mutantes obtidos foram inoculados em citros e tabaco a fim de comparar a capacidade destes de gerar sintomas em relação a linhagem selvagem.

A tabela 2 mostra a concentração de células no inóculo calculada a partir das contagens feitas em placas.

Tabela 2. Concentração de células usadas no experimento de inoculação. 


\begin{tabular}{|c|c|c|}
\hline PlaNTA & Linhagem & $\begin{array}{c}\text { Concentração de células } \\
\text { no inóculo (células / ml) }\end{array}$ \\
\hline \multirow[t]{5}{*}{ Citros } & J1.a.12 & $4 \times 10^{9}$ \\
\hline & GB mut (clone 1) & $3 \times 10^{8}$ \\
\hline & GB mut (clone 2) & $5 \times 10^{9}$ \\
\hline & GF mut (clone 1) & $6 \times 10^{8}$ \\
\hline & GF mut (clone 2) & $6 \times 10^{8}$ \\
\hline \multirow[t]{5}{*}{ Tabaco ( $1^{\mathrm{a}}$ inoculação) } & J1.a.12 & $8 \times 10^{10}$ \\
\hline & GB mut (clone 1) & $2 \times 10^{10}$ \\
\hline & GB mut (clone 2) & $2 \times 10^{10}$ \\
\hline & GF mut (clone 1) & $9 \times 10^{10}$ \\
\hline & GF mut (clone 2) & $2 \times 10^{10}$ \\
\hline \multirow[t]{5}{*}{ Tabaco (2a inoculação) } & J1.a.12 & $1 \times 10^{10}$ \\
\hline & GB mut (clone 1) & $2 \times 10^{10}$ \\
\hline & GB mut (clone 2) & $3 \times 10^{8}$ \\
\hline & GF mut (clone 1) & $5 \times 10^{8}$ \\
\hline & GF mut (clone 2) & $2 \times 10^{8}$ \\
\hline
\end{tabular}

A previsão para o aparecimento dos sintomas em plantas de tabaco inoculadas com a linhagem selvagem é de 45 a 60 dias após a inoculação, enquanto que para citros, a previsão é de 180 dias (Lopes et al. 2000). Mesmo passada esta, não foi possível detectar o aparecimento de sintomas nas plantas de citros ou tabaco.

Esses resultados indicam que a linhagem selvagem usada seja avirulenta ou tenha sua virulência reduzida. Uma explicação para essa perda de 
virulência é a sucessiva repicagem das linhagens em meio de cultura, o que sabidamente causa uma redução na virulência de Xylella fastidiosa (Monteiro et al. 2001a). É provável que a linhagem J1a12 seja uma linhagem naturalmente pouco virulenta e que as repicagens sucessivas tenham comprometido a sua capacidade de colonizar a planta e desenvolver os sintomas.

As inoculações em citros completaram apenas 7 meses (210 dias), ainda existindo a possibilidade de que os sintomas apareçam nessas plantas.

Para resolver a questão da influência da goma fastidiana na patogenicidade de $X$. fastidiosa, novos mutantes gum utilizando-se a estratégia de troca alélica com o gene de contra-seleção $s a c B$, serão gerados a partir de uma outra linhagem transformável altamente virulenta, a B111 (Diva Teixeira, comunicação pessoal). 


\section{CONCLUSÕES}

Foram obtidos mutantes para os genes gumB e gum $F$ do operon gum de Xylella fastidiosa

Não foi observada qualquer influência da glicose sobre a expressão do operon gum de $X$. fastidiosa

Foi descoberta a existência de um promotor funcional localizado na fita complementar do operon gum.

Não foram detectadas diferenças morfológicas entre os mutantes gum e a linhagem selvagem J1a12 de $X$. fastidiosa.

A inativação dos genes gum não afetou a adesão de $X$. fastidiosa "in vitro".

Foram observadas por cromatografia diferenças significativas entre os perfis protéicos dos mutantes gum e da linhagem selvagem J1a12 de $X$. fastidiosa, indicando pleiotropia para esses genes.

Sendo a linhagem usada avirulenta, não foi possível avaliar o efeito dessas mutações na patogênese de $X$. fastidiosa. 


\section{REFERÊNCIAS BIBLIOGRÁFICAS}

ALBERTS, B.; JOHNSON, A.; LEWIS, J.; RAFF, M.; ROBERTS, K.; WALTER, P. Molecular biology of the cell. 4.ed. New York: Garland Science, 2002. 1463p.

BAULARD, A.; KREMER, L.; LOCHT, C. Efficient homologous recombination in fast-growing and slow-growing mycobacteria. Journal of Bacteriology, v.178, n.11, p.3091-3098, 1996.

BERISHA, B.; CHEN, Y.D.; ZHANG, G.Y.; XU, B.Y.; CHEN, T.A. Isolation of Pierce's disease bacteria from grapevines in Europe. European Journal of Plant Pathology, v.104, n.11, p.427-433, 1998.

BHATTACHARYYA, A.; STILWAGEN, S.; IVANOVA, N.; D'SOUZA, M.; BERNAL, A.; LYKIDIS, A.; KAPATRAL, V.; ANDERSON, I.; LARSEN, N.; LOS, T.; REZNIK, G.; SELKOV, E. Jr.; WALUNAS, T.L.; FEIL, H.; FEIL, W.S.; PURCELL, A.; LASSEZ, J.L.; HAWKINS, T.L.; HASELKORN, R.; OVERBEEK, R.; PREDKI, P.F.; KYRPIDES, N.C. Whole-genome comparative analysis of three phytopathogenic Xylella fastidiosa strains. Proceedings of the National Academy of Science, v.17, n.19, p.1240312408, 2002. 
BRLANSKY, R.H.; TIMMER, I.W.; FRENCH, W.J.; MCCOY, R.E. Colonization of the sharpshooter vectors, Oncometopia igricans, Homalodisca coagulata, by xylem-limited bacteria. Phytopathology, v.73, n.4, p.530-535, 1983.

CARVALHO, M.L.V.; BERETA, M.J.G.; CHAGAS; C.M.; HARAKAWA, R.; PALAZZO, D.A.; ROSSETI, V. Clorose variegada dos citrus: etiologia e manejo. São Paulo: Instituto Biológico, 1996. 13p. (Boletim Técnico, 3)

CHAGAS, C.M.; ROSSETTI, V.; BERETTA, M.J.G. Electronic microscopy studies of xylem-limited bacterium in sweet orange affected with citrus chlorosis disease in Brazil. Journal of Phytopathology, v.134, n.4, p.306312, 1992.

CHANG, C.J.; GARNIER, M.; ZREIK, L.; ROSSETTI, V.; BOVÉ, J.M. Culture and serological detection of the xylem-limited bacterium causing citrus variegated chorosis and its identification as a strain of Xylella fastidiosa. Current Microbiology, v.27, n.3, p.137-142, 1993.

CHOU, F.-L.; CHOU, H.-C.; LIN, Y.-S.; YANG, B.-Y.; LIN, N.-T.; WENG, S.-F.; TSENG, Y.-H. The Xanthomonas campestris gum $\mathrm{D}$ gene required for synthesis of xanthan gum is involved in normal pigmentation and virulence in causing black rot. Biochemical and Biophysical Research Communications, v.233, n.1, p.265-269, 1997.

COSTERTON, J.W.; STEWART, P.S.; GREENBERG, E.P. Bacterial biofilms: a common cause of persistent infections. Science, v.284, n.5418, p.13181322, 1999. 
DAVEY, M.E.; O'TOOLE, G.A. Microbial biofilms: from ecology to molecular genetics. Microbiology and Molecular Biology Reviews, v.64, n.4, p.847-867, 2000.

DAVIS, M.J.; PURCELL, A.H.; THOMSON, S.V. Pierce's disease of grapevines: isolation of the causal bacterium. Science, v.199, p.75-77, 1978.

DE NEGRI, J.D. Clorose variegada dos citros: nova anomalia afetando pomares em São Paulo e Minas Gerais. Campinas, 1990. 6p. (CATI. Comunicado Técnico, 82)

DENNY, T.P. Involvement of bacterial polysaccharides in plant pathogenesis. Annual Review of Phytopathology, v.33, p.173-197, 1995.

DONNENBERG, M.S.; KAPER, J.B. Construction of an eae deletion mutant of enteropathogenic Escherichia coli by using a positive-selection suicide vector. Infection and Immunity, v.59, n.12, p.4310-4317, 1991.

DOW, J.M.; DANIELS, M.J. Xylella genomics and bacterial pathogenicity to plants. Yeast, v.17, n.4, p.263-271, 2000.

DOW, J.M.; FENG, J.X.; BARBER, C.E.; TANG, J.L.; DANIELS, M.J. Novel genes involved in the regulation of pathogenicity factor production within the rpf gene cluster of Xanthomonas campestris. Microbiology, v.146, n.4 p.885-891, 2000.

GAURIVAUD, P.; SOUZA, L.C.A.; VIRGÍLIO, A.C.D.; MARIANO, A.G.; PALMA, R.R.; MONTEIRO, P.B. Gene disruption by homologous recombination in the Xylella fastidiosa citrus variegated chlorosis strain. Applied and Environmental Microbiology, v.68, n.9, p.4658-4665, 2002. 
GOHEEN, A.C.; NYLAND, G.; LOWE, S.K. Association of a rickettsialike organism with Pierce's disease of grapevines. Phytopathology, v.63, p.341-345, 1973.

GUERREIRO, N.; KSENZENKO, V.N.; DJORDJEVIC, M.A.; IVASHINA, T.V.; ROLFE, B.G. Elevated levels of synthesis of over 20 proteins results after mutation of the Rhizobium leguminosarum exopolysaccharide synthesis gene pssA. Journal of Bacteriology, v.182, n.16, p.4521-4532, 2000.

GUILHABERT, M.R.; HOFFMAN, L.M.; MILLS, D.A.; KIRKPATRICK, B.C. Transposon mutagenesis of Xylella fastidiosa by Electroporation of Tn5 synaptic complexes. Molecular Plant-Microbe interactions, v.14, n.6, p.701-706, 2001.

HAMILTON, H.L.; SCHWARTZ, K.J.; DILLARD, J.P. Insertion-duplication mutagenesis of Neisseria: use in characterization of DNA transfer genes in the gonococcal genetic island. Journal of Bacteriology, v.183, n.16, p.4718-4726, 2001.

HARTUNG, J.S.; BERETTA, M.J.G.; BRALANSKY, R.H.; SPISSO, J.; LEE, R.F. Citrus variegated chlorosis bacterium: axenic culture, pathogenicity, and serological relationships whit other strains of Xylella fastidiosa. Phytopathology, v.64, n.3, p.591-597, 1994.

HOPKINS, D.L.; MOLLENHAUER, H.H. Rickettsia-like bacterium associated with Pierce's disease of grapes. Science, v.179, p.298-300, 1973.

HOPKINS, D.L. Xylella fastidiosa xylem-limited bacterial pathogen of plants. Annual Review of Phytopathology, v.27, p.271-290, 1989. 
IELPI, L.; COUSO, R.O.; DANKERT, M.A. Sequential assembly and polymerization of the polyprenol-linked pentasaccharide repeating unit of the xanthan polysaccharide in Xanthomonas campestris. Journal of Bacteriology, v.175, n.9, p.2490-2500, 1993.

KAMPER, S.M.; FRENCH, W.J.; DEKLOET, S.R. Genetic relationships of some fastidious xylem-limited bacteria. International Journal of Systematic Bacteriology, v.35, p.185-188, 1985.

KATZEN, F.; BECKER, A.; ZORREGUIETA, A.; PÜHLER, A.; IELPI, L. Promoter analysis of the Xanthomonas campestris pv. campestris gum operon directing biosynthesis of the xanthan polysaccharide. Journal of Bacteriology, v.178, n.14, p.4313-4318, 1996.

KATZEN, F.; FERREIRO, D.U.; ODDO, C.G.; IELMINI, M.V.; BECKER, A.; PÜHLER, A.; IELPI, L. Xanthomonas campestris pv campestris gum mutants: effects on xanthan biosynthesis and plant virulence. Journal of Bacteriology, v.180, n.7, p.1607-1617, 1998.

KEEN, N.T.; DUMENYO, C.K.; YANG, C.; COOKSEY, D.A. From rags to riches: insights from the first genomic sequence of a plant pathogenic bacterium. Genome Biology, v.1, n.3, p.1019.1-1019.4, 2000.

KEILER, K.C.; SHAPIRO, L.; WILLIAMS, K.P. tmRNAs that encode proteolysis-induced tags are fund in all known bacterial genomes: a twopiece tmRNA functions in Caulobacter. Proceedings of the National Academy of Science, v.97, n.14, p.7778-7783, 2000. 
KEILER, K.C.; WAILER, P.R.; SAUER, R.T. Role of a peptide tagging system in degradation of proteins synthesized from damaged messenger RNA. Science, v.271, n.5251, p.990-993, 1996.

KJAERGAARD, K.; SCHEMBRI, M.A.; HASMAN, H.; KLEMM, P. Antigen 43 from Escherichia coli induces inter and interspecies cell aggregation and changes in colony morphology of Pseudomonas fluorescens. Journal of Bacteriology, v.182, n.17, p.4789-4796, 2000.

LAMBAIS, M.R.; GOLDMAN, M.H.; CAMARGO, L.E.; GOLDMAN, G.H. A genomic aproach to the understanding of Xylella fastidiosa pathogenicity. Current Opinion in Microbiology, v.3, n.5, p.459-462, 2000.

LEITE, B.; ISHIDA, M.L.; ALVES, E.; CARRER, H.; PASCHOLATI, S.F.; KITAJIMA, E.W. Genomics and X-ray microanalysis indicate that $\mathrm{Ca}^{2+}$ and thiols mediate the aggregation and adhesion of Xylella fastidiosa. Brazilian Journal of Medical and Biological Research, v.35, n.6, p.645-650, 2002.

LEE, M.S.; SEOK, C.; MORRISON, D.A. Insertion-duplication mutagenesis in Streptococcus pneumoniae: targeting fragment length is a critical parameter in use as a random insertion tool. Applied and Environmental Microbiology, v.64, n.12, p.4796-4802, 1989.

LEU, L.S.; SU, C.C. Isolation, cultivation and pathogenicity of Xylella fastidiosa, the causal bacterium of pear leaf schorch in Taiwan. Plant Disease, v.77, p.642-646, 1993.

LOPES, J.R.S.; BERETTA, M.J.G.; HARAKAVA, R.; ALMEIDA, R.P.P.; KRUGNER, R. A confirmação da transmissão por cigarrinha do agente 
causal da clorose variegada dos citros. Fitopatologia Brasileira, v.21, p.343, 1996. /Resumo/

LOPES, S.A.; RIBEIRO, D.M.; ROBERTO, P.G.; FRANÇA, S.C.; SANTOS, J.M. Nicotiana tabacum as an experimental host for the study of plantXylella fastidiosa Interactions. Plant Disease, v.84, n.8, p.827-830, 2000.

MARQUES, L.L.R.; CERI, H.; MANFIO, G.P.; REID, D.M.; OLSON, M.E. Characterization of biofilm formation by Xylella fastidiosa in vitro. Plant Disease, v.86, n.6, p.633-638, 2002.

MEIDANIS, J.; BRAGA, M.D.V.; VERJOVSKIALMEIDA, S. Whole-genome analysis of transporters in the plant pathogen Xylella fastidiosa. Microbiology and Molecular Biology Reviews, v.66, n.2, p.272-299, 2002.

MOLNOS, J.; LANGE, R.; AMREIN, K.E.; An improoved vector system for insertional gene inactivation inspired by the tmRNA-tagging system of $S$. pneumoniae. Journal of Microbiological Methods, v.42, n.2, p.197-201, 2000.

MONTEIRO, P.B.; RENAUDIN, J.; JAGOUEIX-EVEILLARD, S.; AYRES, A.J.; GARNIER, M.; BOVÉ, J.M. Catharanthus roseus, an Experimental Host Plant for the Citrus Strain of Xylella fastidiosa. Plant Disease. v.85, n.1 p.246-251, 2001a.

MONTEIRO, P.B.; TEIXEIRA, D.C.; PALMA, R.R.; GARNIER, M.; BOVÉ, J.-M.; RENAUDIN, J. Stable transformation of the Xylella fastidiosa citrus variegated chlorosis strain with oriC plasmids. Applied and Environmental Microbiology, v.67, n.5, p.2263-2269, 2001b. 
NETO, J.F.S.; KOIDE, T.; GOMES, S.L.; MARQUES, M.V. Site-directed gene disruption in Xylella fastidiosa. FEMS Microbiology Letters, v.210, n.1, p.105-110, 2001.

NEWMAN, M.-A.; CONRADS-STRAUCH, J.; SCOFIELD, G.; DANIELS, M.J.; DOW, J.M. Defense-related gene induction in Brassica campestris in response to defined mutants of Xanthomonas campestrias with altered pathogenicity. Molecular Plant-Microbe Interactions, v.7, n.5, p.553-563, 1994.

PAULSEN, I.T.; BENESS, A.M.; SAIER J.; M.H. Computer based analyses of the protein constituents of transport systems catalyzing export of complex carbohydrates in bacteria. Microbiology, v.143, p.2685-2699, 1997.

POLLOCK, T.J.; THORNE, L.; YAMAZAKI, M.; MIKOLAJCZAK, M.J.; ARMENTROUT, R.W. Mechanism of bacitracin resistance in Gram-negative bacteria that synthesize exopolysaccharides. Journal of Bacteriology, v.176, n.20, p.6229-6237, 1994.

PURCELL, A.H.; FINLAY, A.H. Evidence for noncirculative transmission of Pierce's disease bacterium by sharpshooter leafhoppers. Phytopathology, v.69, p.393-395, 1979.

PURCELL, A.H.; HOPKINS, D.L. Fastidious xylem-limited bacterial plant pathogens. Annual Review of Phytopathology, v.34, p.131-151, 1996.

PURCELL, A.H. Xylella fastidiosa, a regional problem or global threat? Journal of Plant Pathology, v.79, p.99-105, 1997. 
QIN, X.; HARTUNG, J.S. Construction of a shuttle vector and transformation of Xylella fastidiosa with plamid DNA. Current Microbiology, v.43, p.158-162, 2001.

RAJU, C.B.; WELLS, J. Diseases caused by fastidious xylem-limited bacteria. Plant Disease, v.70, p.182-186, 1986.

ROBERTO, S.R.; COUTINHO, A.; LIMA, J.E.O.; MIRANDA, V.S.; CARLOS, E.F. Transmissão de Xylella fastidiosa pelas cigarrinha Dilobopterus costalimai, Acrogonia terminalis e Oncometopia facialis em citros. Fitopatologia Brasileira, v.21, p.517-518, 1996.

ROSSETI, V.; GARNIER, M.; BOVE, J.M.; BERETTA, M.J.G.; TEIXEIRA, A.R.T.; QUAGGIO, J.A.; NEGRI, J.D. de Présence de bactéries dans xylème d'orangers atteints de chlorose variégée, une nouvelale maladis des agrumes au brésil. Comptes Rendus de L'academie des science - Paris, v.310, série III, p.345-349, 1990.

SAMBROOK, J.; FRITSCH, E.F.; MANIATIS, T.E. Molecular cloning: a laboratory manual. Cold Spring Harbor: Laboratory Press, 1989. 1567p.

SILVA, F.R. da; VetTORE, A.L.; KEMPER, E.L.; LEITE, A.; ARRUDA, P. Fastidian gum: the Xylella fastidiosa exopolysaccharide possibly involved in bacterial pathogenicity. FEMS Microbiology Letters, v.203, n.2, p.165-171, 2001. 
SIMPSON, A.J.; REINACH, F.C.; ARRUDA, P. et al. The genome sequence of plant pathogen Xylella fastidiosa. Nature, v.406, p.151-159, 2000.

SOLANO, C.; SESMA, B; ALVAREZ, M.; HUMPHREY, T.J.; THORNS, C.J.; GAMAZO, C. Discrimination of strains of Salmonella enteritidis with differing levels of virulence by an in vitro glass adherence test. Journal of Clinical Microbiology, v.36, n.3, p.674-678, 1998.

TANG, J.L.; LIU, Y.N.; BARBER, C.E.; DOW, J.M.; WOOTTON, J.C.; DANIELS, M.J. Genetic and molecular analysis of a cluster of rpf genes involved in positive regulation of synthesis of extracellular enzymes and polysaccharide in Xanthomonas campestris pathovar campestris. Molecular and General Genetics, v.223, n.3, p.409-417, 1991.

VOJNOV, A.A.; SLATER, H.; DANIELS, M.J.; DOW, J.M. Expression of the gum operon directing xanthan biosynthesis in Xanthomonas campestris and its regulation in planta. Molecular Plant-Microbe Interactions, v.14, n.6, p.768-774, 2001.

VOJNOV, A.A.; ZORREGUIETA, A.; DOW, J.M.; DANIELS, M.J.; DANKERT, M.A. Evidence for a role for the gumB and gum $\mathrm{C}$ gene products in the formation of xanthan from its pentassaccharide repeating unit by Xanthomonas campestris. Microbiology, v.144, p.1487-1493, 1998.

WATNICK, P.; KOLTER, R. Biofilm, city of microbes. Journal of Bacteriology, v.182, n.10, p.2675-2679, 2000.

WELLS, J.M.; RAJU, B.C. Cellular fatty acid composition of six fastidious, Gram-negative, xylem limited bacteria from plants. Current Microbiology, v.10, p.231-236, 1984. 
WELLS, J.M.; RAJU, B.C.; HUNG, H.; WEISBURG W.G.; MANDELCO-PAUL, L.; BRENNER, D.J. Xylella fastidiosa gen. Nov., sp. Nov; Gram-negative, xylem limited, fastidious plant bactéria related to Xanthomonas spp. International Journal of Systematic Bacteriology, v.37, p.136-143, 1987.

WHITELEY, M.; BANGERA, M.G.; BUMGARNER, R.E.; PERSEK, M.R.; TEITZEL, G.M.; LORY, S.; GREENBERG, E.P. Gene expression in Pseudomonas aeruginosa biofilmes. Nature, v.413, p.860-864, 2001.

WHITHCHURCH, C.B.; NIELSEN, T.T.; RAGAS, P.C.; MATTICK, J.S. Extracellular DNA required for biofilm formation. Science, v.295, n.5559, p.1487, 2002. 